\title{
Role of Epichloë Endophytes in Defense Responses of Cool-Season Grasses to Pathogens: A Review
}

\section{Chao Xia, Nana Li, Yawen Zhang, Chunjie Li, Xingxu Zhang, ${ }^{\dagger}$ Zhibiao Nan $^{\dagger}$}

\author{
State Key Laboratory of Grassland Agro-Ecosystems; Key Laboratory of Grassland \\ Livestock Industry Innovation, Ministry of Agriculture and Rural Affairs; \\ and College of Pastoral Agricultural Science and Technology, Lanzhou University, \\ P. O. Box 61, Lanzhou 730020, P. R. China.
}

Symbioses of plants and animals with microorganisms have led to major transitions in the evolution of life (Margulis 1996). Many coolseason grasses are hosts of the fungal genus Epichlö̈, for which the asexual members had previously been classified as Neotyphodium spp. (Leuchtmann et al. 2014). These endophytes spend their life cycle living in the intercellular space of aerial tissues without causing obvious symptoms in or injury to the host (Christensen et al. 2008; Kuldau and Bacon 2008; Nan and Li 2004). Although the first association involving a member of this genus was found in 1898 (Sampson 1933), the stimulus that led to the current interest in Epichlö endophytes was the link established in 1977 between the presence of an endophyte in tall fescue (Festuca arundinacea) and a toxicosis problem in grazing cattle (Bacon et al. 1977). Following this, the symbiosis between Pooideae grasses and Epichloë endophytes has attracted great interest from researchers around the world (Leuchtmann et al. 2014; Saikkonen et al. 2006; Song et al. 2016; Tadych et al. 2014). Presently, 45 species of Epichloë endophytes have been reported in the world (Leuchtmann et al. 2014; Shymanovich et al. 2017; Song et al. 2016).

The associations between grasses and these endophytic fungi are generally considered to be mutualistic (Müller and Krauss 2005). Host plants provide photosynthate and shelter for these endophytes, and their presence can improve the ability of the host grass to persist when exposed to abiotic stresses, such as drought (Gundel et al. 2016; Hahn et al. 2008; Hesse et al. 2003; Kane 2011; Malinowski and Belesky 2000), salt (Dinneny 2015; Sabzalian and Mirlohi 2010; Song et al. 2015a), heavy metals (Malinowski et al. 2004; Zhang et al. 2010a, b), cold (Chen et al. 2016; Zhou et al. 2015), and waterlogging (Song et al. 2015b), and to biotic stresses, such as livestock (Cheplick and Clay 1988; Filipov et al. 1998), birds (Pennell and

${ }^{\dagger}$ Corresponding authors: X. X. Zhang, E-mail: xxzhang@1zu.edu.cn; and Z. B. Nan, E-mail: zhibiao@1zu.edu.cn

Funding: This research was financially supported by the National Basic Research Program of China (2014CB138702), the National Nature Science Foundation of China (31402132 and 31772665), and the Fundamental Research Funds for the Central Universities (lzujbky-2016-12, lzujbky-2016177, lzujbky-2016-19).

Accepted for publication 18 June 2018.

(C) 2018 The American Phytopathological Society
Rolston 2012), insects (Barker et al. 2015; Shiba et al. 2011; Yule et al. 2011; Zhang et al. 2012), nematodes (Eerens et al. 1998; Guo et al. 2016; Latch 1993), and pathogens (Ma et al. 2015; Sabzalian et al. 2012; Vignale et al. 2013; Xia et al. 2015, 2016). Therefore, mutualism plays important roles in influencing species coexistence and determining community composition (Umbanhowar and McCann 2005; Yao et al. 2015).

Disease resistance is the key factor in the quality of all agricultural crops, including forage grasses (Wiewióra et al. 2015). The incidence and severity of plant disease, especially foliar diseases, pose a serious threat not only to cereal production (Fisher et al. 2012) but also to forage production, which further influences livestock production. Fungicide application can be employed to remit damage from fungal disease, but it should be noted that this strategy has its limitations (Walter et al. 2005). It almost certainly would cause environmental problems and probably result in pathogens acquiring fungicide tolerance. Therefore, breeding resistant cultivars is regarded as the most economical and environmentally friendly strategy because of the reduction in chemical input into the environment (Huang and Roder 2004). One of the underexplored approaches to breed resistant cultivars is the use of symbiotic fungal endophytes. In 1983, in a pioneering study, Shimanuki and Sato (1983) first found that the presence of Epichlö endophytes suppressed fungal diseases in the host grasses. Following this finding, this area of research has attracted great interest around the world. Therefore, it is necessary to summarize advances in research regarding resistance to plant diseases caused by Epichloë spp. endophytic fungi and to try to reveal the disease resistance mechanisms. Here, we highlight the latest advances in our understanding of the interactions among host plants, endophytic fungi, and pathogenic fungi and of the potential mechanisms of inhibition of plant pathogenic fungi by endophytic fungi to obtain a broader understanding of fungal endophyte effects on hosts that could create new opportunities for managing or introducing fungal symbioses in both non-agronomic and agronomic ecosystems.

\section{The Interaction Between Symbiosis and Pathogenic Fungi}

The effect of endophytes on the growth of pathogenic fungi in vitro using a dual-culture test. The previous research regarding the antagonistic effect of endophytes on pathogens in a dual-culture test mainly focused on the Epichloë coenophialum, E. uncinatum, and E. festucae var. lolii endophytes. These endophytes colonize tall fescue, meadow fescue (Lolium pratensis), and perennial ryegrass 
(L. perenne), respectively. These three Epichlö̈ endophytes caused variable inhibition of the growth of fungi, including Alternaria alternata, Bipolaris sorokiniana, Drechslera spp., Fusarium spp., and Rhizoctonia spp. The resistances of some other Epichloë endophytes to pathogenic fungi were also occasionally reported (Table 1). For example, E. gansuensis endophytes could inhibit the growth of $\mathrm{Cur}$ vularia sp., Phomopsis sp., and Fusarium acuminatum (Li et al. 2007b). All dual-culture tests to date show that the inhibitory effects of Epichlö̈ endophytes on pathogenic fungi are influenced by the species and genotype of the endophyte, the temperature of the growing environment, and the time of the dual-culture test.

The positive effect of Epichlö̈ endophytes on plant defense has been traditionally attributed to alkaloids, and the role of alkaloids in protecting grasses associated with Epichloë endophytes has been extensively documented (Bastias et al. 2017). Different species of endophyte associate with different grasses that produce different kinds of alkaloids (Table 2) (Bush et al. 1997; Schardl and Phillips 1997). Thus, the inhibitory effects on the growth of pathogenic fungi are different. Beyond that, the inhibitory effect is also influenced by the genotype of the endophyte. The same species of endophytes isolated from different grasses show different resistance to various pathogens. Ten strains of the E. festucae var. lolii endophyte were isolated from 22 perennial ryegrass plants, and seven of them significantly inhibited the growth of $F$. avenaceum and Rhizoctonia solani, while the other three strains had no effect on either pathogen's growth (Pańka 2008). In addition, even if the endophytes are the same species or were isolated from the same host grass, their resistance to pathogens may be different. For instance, there were four Epichloë endophyte strains isolated from perennial ryegrass, but only one of them had the strongest inhibitory activity against A. alternata,
B. sorokiniana, Curvularia lunata, and Drechslera sp. compared with the other endophytes (Ma and Nan 2011a). Christensen et al. (1991) found similar results concerning isolates of the E. festucae var. lolii endophyte (and/or E. typhinum) tested with Colletotrichum graminicola and Drechslera erythrospila.

In addition to the species and genotype of the endophyte, the resistance of Epichlö̈ endophytes to pathogenic fungi may be determined by the external environment, especially temperature. The notable mycelium growth inhibition of $B$. sorokiniana, $F$. avenaceum, F. equiseti, Gaeumannomyces graminis, and Microdochium nivale by endophytes appeared at $30^{\circ} \mathrm{C}$, but this negative effect disappeared for B. sorokiniana and $M$. nivalis at $10^{\circ} \mathrm{C}$ and for $F$. equiseti at 10 and $20^{\circ} \mathrm{C}$ (Pańka 2005). This finding indicated that the inhibitory effect of the E. coenophialum endophyte is more effective at a relatively high temperature. The resistance of another endophyte, E. uncinatum, to pathogenic fungi was also determined by temperature. The difference was that the growth of $G$. graminis, $F$. equiseti, $F$. culmorum, and $F$. graminearum was notably inhibited by this endophyte at $10^{\circ} \mathrm{C}$. However, this negative effect on the growth of $F$. equiseti and $F$. graminearum disappeared at 20 and $30^{\circ} \mathrm{C}$ (Pańka et al. 2006), which means that the inhibitory effect of the E. uncinatum endophyte may be more effective at a relatively low temperature.

Recent research also suggested that one potential novel species of Epichloë endophyte (recorded as XH03) isolated from Chinese fescue (Festuca sinensis) remarkably inhibited the growth of $A$. alternata, B. sorokiniana, and $C$. lunata by at least $50 \%$, but the inhibitory effect was not effective in the long term (Zhou et al. 2015). This phenomenon indicated that the inhibitory effect of endophytes on pathogen growth may be time-constrained. After all, external culture conditions in vitro are quite different from the native

Table 1. The antagonistic effect of endophyte on the growth of pathogenic fungi in vitro using a dual-culture test

\begin{tabular}{|c|c|c|c|}
\hline Pathogen & Endophyte & Host & References \\
\hline $\begin{array}{l}\text { Alternaria alternata } \\
\text { Cladosporium cladosporioides } \\
\text { Nigrospora sphaerice } \\
\text { Periconia macrospinosa } \\
\text { Phoma sorghina } \\
\text { Rhizoctonia cerealis } \\
\text { Trichoderma harzianum }\end{array}$ & Epichloë coenophialum & Festuca arundinacea & White and Cole 1985 \\
\hline Colletorichum graminicola & E. festucae var. lolii & Lolium perenne & Christensen et al. 1991 \\
\hline Drechslera erythrospila & E. festucae var. lolii & L. perenne & Christensen 1996; Christensen et al. 1991 \\
\hline C. graminicola & E. coenophialum or possibly E. typhinum & F. arundinacea & Christensen and Latch 1991 \\
\hline D. erythrospila & E. coenophialum or possibly E. typhinum & F. arundinacea & Christensen and Latch 1991 \\
\hline Puccinia coronata & E. coenophialum or possibly E. typhinum & F. arundinacea & Christensen and Latch 1991 \\
\hline Rhizoctonia zeae & E. lolii & Festuca spp. or L. perenne & Christensen 1996 \\
\hline $\begin{array}{l}\text { Drechslera andersenii } \\
\text { Drechslera siccans } \\
\text { Drechslera teres } \\
\text { Drechslera poae }\end{array}$ & E. lolii & No & Holzmann-Wirth et al. 2000 \\
\hline $\begin{array}{l}\text { A. alternata } \\
\text { Bipolaris sorokiniana } \\
\text { Curvularia lunata } \\
\text { Fusarium acuminatum }\end{array}$ & E. gansuensis & Achnatherum inebrians & Li et al. $2007 \mathrm{a}$ \\
\hline R. cerealis & E. lolii & L. perenne & Pańka 2008 \\
\hline $\begin{array}{l}\text { Cladosporium sp. } \\
\text { Curvularia sp. } \\
\text { Phomonsis sn }\end{array}$ & Epichloë sp. & A. sibiricum & Xie et al. 2008 \\
\hline $\begin{array}{l}\text { Phomopsis } \mathrm{sp} \text {. } \\
\text { A. alternata } \\
\text { B. sorokiniana } \\
\text { C. lunata } \\
\text { Drechslera } \mathrm{sp} .\end{array}$ & Epichloë sp. & L. perenne & Ma and Nan 2011a \\
\hline $\begin{array}{l}\text { B. sorokiniana } \\
\text { Microdochium nivale } \\
\text { Fusarium equiseti } \\
\text { Rhizoctonia solani }\end{array}$ & E. uncinatum and E. lolii & L. perenne and $F$. pratensis & Pańka 2011 \\
\hline $\begin{array}{l}\text { A. alternata } \\
\text { B. sorokiniana } \\
\text { C. lunata }\end{array}$ & Epichloë sp. & F. sinensis & Zhou et al., 2015 \\
\hline
\end{tabular}


growth conditions of endophyte fungi, and their slow growth rate is one of their weaknesses, especially when they face competition from rapid-growth pathogenic fungi for a long period under dualculture conditions. Further, for secondary metabolites, which are regarded as crucial substances for symbiosis protection, the concentration produced by the endophyte itself is far lower than the concentration of substances such as alkaloids produced by endophyte-grass symbiosis ( $\mathrm{Li} 2005$ ).

The antagonistic effect of endophytes on pathogenic fungi on detached leaves. Most of the studies indicated that Epichlö̈ endophytes inhibit the growth of various pathogenic fungi (Table 3). Endophyte infection could inhibit pathogen invasion, lesion development, or both, manifested as a reduction in the number or size of disease lesions of endophyte-infected (E+) leaves (Li et al. 2007a; Nan and Li 2000; Sun 2015; Tian et al. 2008; Zhou et al. 2015). However, the results of previous research on the antagonistic effect of endophytes on pathogens on detached leaves are inconsistent. There are some exceptions indicating that the growth of some pathogenic fungi would not be affected by the endophyte status of leaves; for example, the E. festucae var. lolii endophyte has no effect on the growth of Ascochyta leptospora on detached perennial ryegrass leaves (Tian et al. 2008), the Epichlö̈ sp. endophyte did not affect the growth of $F$. equiseti on detached Elymus cylindricus leaves (Nan and $\mathrm{Li}$ 2000), and the growth of $C$. lunata was not affected by endophyte status on detached drunken horse grass (Achnatherum inebrians) leaves ( $\mathrm{Li}$ et al. 2007a). In sum, in addition to endophyte status, disease resistance of detached grass leaves was influenced by multiple factors, including the species and genotype of pathogenic fungi, grass genotypes or varieties, and growth conditions (Bonos et al. 2005; Christensen 1996; Latch 1993; Popay and Bonos 2005; Wäli et al. 2006).

The effect of endophytes on the resistance to fungal disease in planta. There is a difference between obtaining fungal inhibition in vitro and obtaining resistance to a plant disease in an endophyteinfected plant. The changes in the host grass induced by the endophyte and environmental factors can influence many relationships that may take place during later stages, including those with pathogens (Pérez et al. 2017). For instance, an endophyte originating from three different cultivars of meadow ryegrass inhibited the growth of Typhula ishikariensis in vitro in a dual-culture test. However, compared with the endophyte-free (E-) grasses, the presence of endophytes in the host plant led to the plant becoming more susceptible to T. ishikariensis in planta (Wäli et al. 2006). As another example, nearly all E. gansuensis endophytes isolated from drunken horse grass could inhibit the growth and sporulation of $B$. sorokiniana in in vitro dual-culture tests, while the endophyte infection of drunken horse grass did not significantly enhance resistance to leaf blight disease, which is caused by the same pathogen under uncontrolled natural field conditions in planta (Li et al. 2007b). This difference may be induced by the difference in inhibitory substance

Table 2. Some main symbioses of grasses with Epichloë endophytes and their symbiosis-related alkaloids (Modified from Schardl and Phillips [1997]) ${ }^{\mathrm{a}}$

\begin{tabular}{|c|c|c|c|c|c|}
\hline Endophyte & Host & $\mathbf{E A}^{\mathbf{b}}$ & ID $^{c}$ & SAP ${ }^{d}$ & $\mathbf{P P}^{\mathbf{c}}$ \\
\hline Epichloё coenophialum & Festuca arundinacea & $+/-$ & - & + & + \\
\hline E. festucae var. lolii & Lolium perenne & $+1-$ & $+1-$ & - & $+1-$ \\
\hline E. festucae & Festuca spp. & $+/-$ & $+/-$ & $+/-$ & $+/-$ \\
\hline E. gansuensis/E. inebrians & Achnatherum inebrians & + & + & - & - \\
\hline E. uncinatum & F. pratensis & - & - & + & - \\
\hline E. typhina & Various C3 grasses & - & - & - & $+1-$ \\
\hline
\end{tabular}

${ }^{a}+$ : found in all associations to date; +l-: found in some but not all associations; -: found in none of the associations to date.

${ }^{\mathrm{b}}$ Ergot alkaloids.

${ }^{\mathrm{c}}$ Indole-diterpenes (tremorgens, such as lolitrem B).

${ }^{\mathrm{d}}$ Saturated aminopyrrolizidines (lolines).

${ }^{\mathrm{e}}$ Pyrrolopyrazines (peramine).

Table 3. The antagonistic effect of endophyte on pathogenic fungi in detached leaves ${ }^{\mathrm{a}}$

\begin{tabular}{|c|c|c|c|c|c|c|c|c|c|c|}
\hline \multirow[b]{2}{*}{ Symbiosis/pathogens } & \multicolumn{2}{|c|}{$\begin{array}{c}\text { Lolium perenne- } \\
\text { Epichloë festucae } \\
\text { var. lolii } \\
\end{array}$} & \multicolumn{2}{|c|}{$\begin{array}{c}\text { Eylmus } \\
\text { cylindricus- } \\
\text { Epichloë sp. }\end{array}$} & \multicolumn{2}{|c|}{$\begin{array}{c}\text { Festuca } \\
\text { sinensis- } \\
\text { Epichloë sp. }\end{array}$} & \multicolumn{2}{|c|}{$\begin{array}{c}\text { Achnatherum } \\
\text { inebrians- } \\
\text { Epichlö̈ } \\
\text { gansuensis } \\
\end{array}$} & \multicolumn{2}{|c|}{$\begin{array}{c}\text { Hordeum } \\
\text { brevisubulatum- } \\
\text { Epichloë sp. }\end{array}$} \\
\hline & $\mathrm{NL}^{\mathrm{b}}$ & $\mathrm{SL}^{\mathrm{c}}$ & NL & SL & NL & SL & NL & SL & NL & SL \\
\hline Alternaria alternata & + & + & + & + & + & + & + & + & + & + \\
\hline Ascochyta leptospora & - & - & & & & & + & + & & \\
\hline Bipolaris sorokiniana & + & + & & & + & + & & & + & + \\
\hline Claviceps purpurea & & & & & & & & & + & + \\
\hline Clonostachys rosea & & & & & & & - & + & & \\
\hline $\begin{array}{l}\text { Curvularia lunata } \\
\text { Drechslera ervthrospila }\end{array}$ & + & + & & & + & + & - & - & + & $\begin{array}{l}+ \\
+\end{array}$ \\
\hline $\begin{array}{l}\text { Drechslera erythrospila } \\
\text { Fusarium acuminatum }\end{array}$ & + & + & & & + & + & - & + & + & + \\
\hline Fusarium avenaceum & + & + & + & + & & & - & + & + & + \\
\hline Fusarium chlamydosporum & + & + & & & & & + & + & & \\
\hline Fusarium culmorum & & & + & + & & & & & & \\
\hline Fusarium equiseti & & & + & + & & & & & & \\
\hline Fusarium oxysporum & + & + & + & + & & & + & + & & \\
\hline Fusarium semitectum & & & & & & & & & + & + \\
\hline Fusarium solani & + & + & & & & & + & + & + & + \\
\hline
\end{tabular}

${ }^{a}+:$ the effect of endophyte on plant resistance to pathogens is positive; -: the effect of endophyte on plant resistance to pathogens is neutral; empty: no investigation. References: Li et al. 2007a; Nan and Li 2000; Sun 2015; Tian et al. 2008; Zhou et al. 2015.

${ }^{\mathrm{b}}$ Number of lesions.

${ }^{\mathrm{c}}$ Length of lesions. 
production in vitro compared with that in planta (Christensen 1996). However, the disease resistance observed during the in vitro test does not completely disappear in planta. Most of the previous research on disease resistance of grass-endophytic fungi symbioses, which were carried out in field conditions or in a greenhouse, obtained similar results with in vitro assays (Table 4).

The effect of endophytes on the resistance to fungal disease under field conditions. In 1983, pioneering research carried out by Shimanuki and Sato found that the infection rate of the pathogenic fungus Blastocladia pringsheimii of timothy grass (Phleum pratense) could notably decrease when the host plant was infected by the E. typhina endophyte under field conditions (Shimanuki and Sato 1983). This is the first study to ever report such an association. Since then, researchers have carried out many related field experiments to shed new light on the relationship between pathogenic fungi and endophytic fungi, and most of them have obtained similar results. Infection by the E. coenophialum endophyte decreased the spore numbers of Alternaria sp. on tall fescue (Chu-Chou et al. 1992) and enhanced resistance to brown leaf spot, damping off (Schmidt and Scehovic 1994), and crown rust diseases (Li et al. 2007b). Research on perennial ryegrass parallels the results in tall fescue; the presence of the E. festucae var. lolii endophyte could notably increase the resistance of a host grass to a leaf spot disease induced by Pyrenophora semeniperda (Wheatley et al. 2000). Compared with E- grasses, endophyte-infected perennial ryegrass had a stronger resistance to rust disease caused by Puccinia sp. (Ma and Nan 2011b). The E. occultans endophyte reduced the disease incidence and severity caused by Claviceps purpurea on Italian ryegrass (Lolium multiflorum) (Pérez et al. 2017). In addition, the Epichlö sp. endophyte could alleviate the negative effects of head

Table 4. The effects of endophytes on the resistance to the pathogenic fungal in planta

\begin{tabular}{|c|c|c|c|c|}
\hline Pathogens & Hosts & Endophytes & Effects & References \\
\hline \multirow[t]{4}{*}{ Alternaria alternata } & Lolium perenne & Epichloë festucae var. lolii & $\begin{array}{l}\text { E+ grass had higher SOD and POD } \\
\text { enzyme activity and developed small } \\
\text { lesions than those from E- }\end{array}$ & Tian et al. 2008 \\
\hline & Hordeum brevisubulatum & Epichloë sp. & $\begin{array}{l}\mathrm{E}+\text { grass had higher plant height, tiller } \\
\text { number and biomass than } \mathrm{E}-\text { grass }\end{array}$ & Sun 2015 \\
\hline & Agropyron cristatum & Epichloë sp. & $\begin{array}{l}\text { The percentage of fungi isolated from the } \\
\text { E+ grass was significantly lower than } \\
\text { that from E- grass }\end{array}$ & Nan and Li 2000 \\
\hline & Elymus cylindricus & Epichloë sp. & $\begin{array}{l}\text { The percentage of fungi isolated from the } \\
\text { E+ grass was significantly lower than } \\
\text { that from E- grass }\end{array}$ & Nan and Li 2000 \\
\hline Aspergillus flavus & Puccinellia distans & E. typhina & $\begin{array}{l}\text { The percentage of fungi isolated from the } \\
\text { E+ seeds was significantly lower than } \\
\text { that from E- seeds }\end{array}$ & Górzyńska et al. 2017 \\
\hline \multirow[t]{4}{*}{ Bipolaris sorokiniana } & L. perenne & E. festucae var. lolii & $\begin{array}{l}\text { E+ grass had higher POD enzyme activity } \\
\text { and developed small lesions than those } \\
\text { from E- }\end{array}$ & Tian et al. 2008 \\
\hline & Festuca pratensis & E. uncinatum & $\begin{array}{l}\text { Endophyte significantly decreased the } \\
\text { infection of pathogen, but the infection } \\
\text { was also affected by weather conditions. }\end{array}$ & Pańka et al. 2011 \\
\hline & Leymus chinensis & Epichloë sp. & $\begin{array}{l}\text { E+ grasses had smaller lesion area of the } \\
\text { leaves than E- grasses }\end{array}$ & Wang et al. 2016 \\
\hline & H. brevisubulatum & Epichloë sp. & $\begin{array}{l}\mathrm{E}+\text { grasses had higher plant height, tiller } \\
\text { number and biomass than } \mathrm{E}-\text { grass }\end{array}$ & Sun 2015 \\
\hline \multirow[t]{2}{*}{ Blumeria graminis } & Achnatherum inebrians & E. gansuensis & $\begin{array}{l}\text { E+ grasses had lower disease incidence, } \\
\text { higher SOD and POD enzyme activity, } \\
\text { chlorophyll and proline content. }\end{array}$ & Liu et al. 2015 \\
\hline & & & $\begin{array}{l}\text { E+ grasses had lower disease incidence, } \\
\text { higher tiller numbers biomass and } \\
\text { greater photosynthetic ability than E- } \\
\text { grasses }\end{array}$ & Xia et al. 2015, 2016 \\
\hline \multirow[t]{2}{*}{$\begin{array}{l}\text { Cladosporium } \\
\text { herbarum }\end{array}$} & Agropyron cristatum & Epichloë sp. & $\begin{array}{l}\text { The percentage of fungi isolated from the } \\
\text { E+ grass was significantly lower than } \\
\text { that from E- grass }\end{array}$ & Nan and Li 2000 \\
\hline & E. cylindricus & Epichloë sp. & $\begin{array}{l}\text { The percentage of fungi isolated from the } \\
\text { E+ grass was significantly lower than } \\
\text { that from E- grass }\end{array}$ & Nan and Li 2000 \\
\hline Claviceps purpurea & Lolium muliflorum & E. occultans & $\begin{array}{l}\text { Both pathogen incidence and severity } \\
\text { were twofold lower in E+ plants than in } \\
\text { E- ones }\end{array}$ & Pérez et al. 2017 \\
\hline $\begin{array}{l}\text { Chaetomium } \\
\text { nigricolor }\end{array}$ & P. distans & E. typhina & $\begin{array}{l}\text { The percentage of fungi isolated from the } \\
\text { E+ seeds was significantly lower than } \\
\text { that from E- seeds }\end{array}$ & Górzyńska et al. 2017 \\
\hline \multirow[t]{5}{*}{ Curvularia lunata } & L. perenne & E. festucae var. lolii & $\begin{array}{l}\text { E+ grass had higher SOD and POD } \\
\text { enzyme activity and developed small } \\
\text { lesions than those from E- }\end{array}$ & Tian et al. 2008 \\
\hline & L. chinensis & Epichloë sp. & $\begin{array}{l}\text { E+ grasses had smaller lesion area of the } \\
\text { leaves than E- grasses }\end{array}$ & Wang et al. 2016 \\
\hline & H. brevisubulatum & Epichloë sp. & $\begin{array}{l}\text { E+ grass had higher plant height and } \\
\text { biomass than E- grass }\end{array}$ & Sun 2015 \\
\hline & Festuca arundinacea & E. coenophialum & $\begin{array}{l}\text { Endophyte infection reduced lesion } \\
\text { number and spore concentration of the } \\
\text { pathogen }\end{array}$ & Chen et al. 2017 \\
\hline & & & & Continued on next page \\
\hline
\end{tabular}


smut caused by Ustilago bullata on Bromus auleticus grass (Iannone et al. 2017). The pathogenic fungus isolation rate of endophyteinfected leaves of wheatgrass (Agropyron cristatum), E. cylindricus grass, and red fescue (Festuca rubra) collected from northwest China was significantly lower than that of the leaves without an endophyte (Nan and Li 2000). The diversity and incidence of pathogenic fungi in Puccinellia distans seeds were also reduced by the presence of endophytes (Górzyńska et al. 2017). These results also indicated that, from another perspective, endophytes had a certain inhibitory effect on pathogenic fungi in host plants.

The effect of endophytes on resistance to fungal disease under greenhouse conditions. The resistance of symbioses to diseases was inconsistent under greenhouse conditions. The presence of the
E. coenophialum endophyte enhanced the resistance of tall fescue to a sheath blight disease caused by Rhizoctonia zeae (Gwinn and Gavin 1992) and to a leaf spot disease caused by A. alternata (Pańka et al. 2013b), but it did not significantly affect resistance to the rust diseases caused by Puccinia graminis (Pańka et al. 2011) and P. graminis subsp. graminicola (Welty et al. 1991), the powdery mildew disease caused by Blumeria sp., or the root rot caused by Cochliobolus sativa (Trevathan 1996) and foot rot caused by Fusarium oxysporum and F. equiseti (Hume et al. 1997). These results indicate not only that the disease resistance of tall fescue is affected by endophyte status but also that $\mathrm{CO}_{2}$ concentration may be responsible for pathogen development. The research of Chen et al. (2017) found that elevated $\mathrm{CO}_{2}$ decreases the severity of the disease caused by $C$. lunata in E+

Table 4. (Continued from previous page)

\begin{tabular}{|c|c|c|c|c|}
\hline Pathogens & Hosts & Endophytes & Effects & References \\
\hline $\begin{array}{l}\text { Drechslera } \\
\text { erythrospila }\end{array}$ & F. pratensis & E. uncinatum & $\begin{array}{l}\text { Presence of the endophyte inhibited } \\
\text { hyphal growth of various pathogenic } \\
\text { fungi on diseased grass leaves. }\end{array}$ & Christensen 1996 \\
\hline Drechslera siccans & L. perenne & E. festucae var. lolii & $\begin{array}{l}\text { E+ grasses had lower disease infection } \\
\text { than E-, but this benefit effect was } \\
\text { affected by the grass genotypes }\end{array}$ & Wiewióra et al. 2015 \\
\hline \multirow[t]{2}{*}{ Fusarium avenaeum } & L. perenne & E. festucae var. lolii & $\begin{array}{l}\text { E+ grass had higher SOD enzyme activity } \\
\text { and developed small lesions than those } \\
\text { from E- }\end{array}$ & Tian et al. 2008 \\
\hline & H. brevisubulatum & Epichloë sp. & $\begin{array}{l}\text { E+ grass had higher tiller number and } \\
\text { biomass than E- grass }\end{array}$ & Sun 2015 \\
\hline \multirow[t]{2}{*}{ Fusarium oxysporum } & Festuca arizonica & Epichloë sp. & $\begin{array}{l}\text { E+ grasses appear to be more resistant to } \\
\text { the pathogen than E- }\end{array}$ & Reddy and Faeth 2010 \\
\hline & Agropyron cristatum & Epichloë sp. & $\begin{array}{l}\text { The percentage of fungi isolated from the } \\
\text { E+ grass was significantly lower than } \\
\text { that from E- grass }\end{array}$ & Nan and Li 2000 \\
\hline Fusarium poae & L. perenne & E. festucae var. lolii & $\begin{array}{l}\text { The E+ plants had lower disease severity, } \\
\text { but this benefit effect was affected by the } \\
\text { grass genotypes. }\end{array}$ & Pańka et al. 2013a \\
\hline Fusarium semitectum & H. brevisubulatum & Epichloë sp. & $\begin{array}{l}\text { E+ grass had higher plant height, tiller } \\
\text { number and biomass than E- grass }\end{array}$ & Sun 2015 \\
\hline \multirow[t]{2}{*}{ Puccinia spp. } & L. perenne & E. festucae var. lolii & $\begin{array}{l}\text { The height and biomass of E+ grasses } \\
\text { were significantly higher, and the } \\
\text { contents of leaf relative water content, } \\
\text { soluble sugar, chlorophyll, proline, and } \\
\text { photosynthetic capacity and the activity } \\
\text { of SOD and POD were significantly } \\
\text { greater than those of E- }\end{array}$ & Ma and Nan 2011b \\
\hline & F. pratensis & E. uncinatum & $\begin{array}{l}\text { Endophyte did not significantly affect the } \\
\text { infection rate of the pathogen on grasses }\end{array}$ & Pańka et al. 2011 \\
\hline $\begin{array}{l}\text { Pyrenophora } \\
\text { semeniperda }\end{array}$ & L. perenne & E. festucae var. lolii & $\begin{array}{l}\text { E- grasses were more susceptible to } \\
\text { infection with the pathogen than E+ } \\
\text { grasses }\end{array}$ & Wheatley et al. 2000 \\
\hline $\begin{array}{l}\text { Puccinia graminis } \\
\text { subsp. graminicola }\end{array}$ & F. arundinacea & E. coenophialum & $\begin{array}{l}\text { Endophyte did not significantly affect the } \\
\text { infection rate of the pathogen on grasses }\end{array}$ & Welty et al. 1991 \\
\hline \multirow[t]{4}{*}{ Rhizoctonia zeae } & L. perenne & E. festucae var. lolii & $\begin{array}{l}\text { The presence of endophyte inhibited, at } \\
\text { different degrees, the pathogenic fungi } \\
\text { hyphal growth on diseased grass leaves. }\end{array}$ & Christensen 1996 \\
\hline & F. arundinacea & E. coenophialum & $\begin{array}{l}\text { The presence of endophyte inhibited, at } \\
\text { different degrees, the pathogenic fungi } \\
\text { hyphal growth on diseased grass leaves. }\end{array}$ & Christensen 1996 \\
\hline & & & $\begin{array}{l}\text { The E+ grasses had reduced pathogen } \\
\text { infection, but this benefit effect was } \\
\text { affected by the grass genotypes. } \\
\text { Additionally, E+ grasses had a higher } \\
\text { phenolic compounds content }\end{array}$ & Pańka et al. 2013b \\
\hline & F. pratensis & E. uncinatum & $\begin{array}{l}\text { The presence of endophyte inhibited, at } \\
\text { different degrees, the pathogenic fungi } \\
\text { hyphal growth on diseased grass leaves. }\end{array}$ & Christensen 1996 \\
\hline Rhizopus nigricans & P. distans & E. typhina & $\begin{array}{l}\text { The percentage of fungi isolated from the } \\
\text { E+ seeds was significantly lower than } \\
\text { that from E- seeds }\end{array}$ & Górzyńska et al. 2017 \\
\hline $\begin{array}{l}\text { Sclerotinia } \\
\text { homoeocarpa }\end{array}$ & Festuca rubra & E. festucae & $\begin{array}{l}\text { E+ grasses had greater plant density and } \\
\text { support less foliar mycelium of } \\
\text { pathogens than E- grasses }\end{array}$ & Clarke et al. 2006 \\
\hline Typhula ishikariensis & F. pratensis & E. uncinatum & $\begin{array}{l}\text { E- grass had significantly less pathogen } \\
\text { infections than E+ }\end{array}$ & Wäli et al. 2006 \\
\hline
\end{tabular}


and E- tall fescue, and the advantage of E+ over E- grass in pathogen resistance under ambient $\mathrm{CO}_{2}$ disappeared with elevated $\mathrm{CO}_{2}$. The researchers ascribed this change to the change in nutritive quality of grass leaves under various $\mathrm{CO}_{2}$ concentrations. Other relevant studies on Festuca grasses showed that the presence of Epichloë endophytes increased the resistance of fine fescue (Festuca stapfli) to the red thread disease caused by Laetisaria fuciformis and Limnomyces roseipellis (Bonos et al. 2005). An Epichloë endophyte that infected red fescue had stronger resistance than endophyte-free grass to a leaf spot disease caused by Sclerotinia sclerotiorum (Clarke et al. 2006). However, the E. uncinatum endophyte makes meadow ryegrass more susceptible to $T$. ishikariensis, which is considered the pathogen of winter snow mold (Wäli et al. 2006). The studies on other genera of grasses found similar results to those for Festuca. The resistance of perennial ryegrass and wild barley (Hordeum brevisubulatum) to various pathogenic fungi were also enhanced when the plants were infected by endophytes, manifesting as more biomass and higher antioxidant substance content of endophyte-infected grasses under pathogen stress (Sun 2015; Tian et al. 2008). E. gansuensis endophytes could enhance the resistance of drunken horse grass to powdery mildew disease caused by Blumeria graminis, manifesting as greater accumulation of dry matter, improved photosynthesis (Xia et al. 2015, 2016), amelioration of the osmotic adjustment substance content, and increased antioxidant substance content (Li et al. 2007b; Liu et al. 2015). Additionally, a study on Chinese wildrye (Leymus chinensis) indicated that endophytes could enhance the resistance to $B$. sorokiniana and $C$. lunata of host grasses by activating a rapid defense reaction in the plants, and this advantage of E+ over Eplants could be strengthened by predrought treatment (Wang et al. 2016).

The effect of endophytes on resistance to viral diseases. Epichloë is an endophyte that not only can inhibit the expansion of disease caused by fungal pathogens but also has a certain resistance to viral diseases. Previous studies showed that Epichlö endophytes could also enhance the resistance of host grasses to viral diseases via deterrence of aphids because some of the aphids are important vectors of viral diseases (Guy and Davis 2002; Mahmood et al. 1993). Studies carried out in America and Australia found that $E$. coenophialum could deter feeding by aphids (Rhopalosiphum padi), and this kind of aphid is regarded as one of the most important vectors of barley yellow dwarf virus (BYDV). Therefore, the presence of endophytes decreased the incidence of BYDV in their host grass (Guy and Davis 2002; Mahmood et al. 1993). However, there was no positive or negative correlation between BYDV incidence and the infection rate of the perennial ryegrass endophyte E. festucae var. lolii (Guy 1992). This may be explained by the finding of Latch et al. (1985) that $R$. padi showed no preference for E. festucae var. loliiinfected or uninfected ryegrass, but most of the $R$. padi attempted to move from $E$. coenophialum-infected to uninfected tall fescue grasses.

\section{How Do Epichloë Endophytes Help Host Grasses Tolerate Plant Disease?}

There is clear evidence that a diverse group of microbes is essential for promoting their host plant's adaptation to pathogenic fungi stress (Van Wees et al. 2008). Endophytes might be critical for host plants to address the three-way interaction among plant, pathogen, and endophyte. In this section, we aim to summarize current knowledge regarding the mechanisms of action of Epichloë endophytes accompanied by the physical, physiological, and molecular response of grass to pathogenic fungi stress. Based on previous studies, we propose that the Epichloe endophyte reduces the disease incidence rate of the host grass mainly through two different ways, one of which is preventing the occurrence of disease, and the other is inhibiting the development of disease. All in all, ecological occupation and antifungal substance production might be two of the major reasons that endophytes promote the resistance of hosts to pathogenic microorganisms. During recent years, it has been assumed that there is great potential for fungal endophytes as biological control agents based on production of antifungal chemicals, mycoparasitism, or physical occupation (Pal and Gardener 2006; Rivera-Varas et al. 2007).
Preventing the occurrence of disease. Control of pathogen transmission. Secondary metabolites are a class of chemical compounds of considerable biological and medical importance (Jarmusch et al. 2016) and play a key role in the adaptation of plants to various environments (Bourgaud et al. 2001). Most studies of secondary metabolites of the symbioses between grass and the Epichlö endophytes have considered alkaloids (Ludwig-Müller 2015; Young et al. 2015). Alkaloids have been regarded as some of the toxins that cause mammalian herbivore and insect poisoning (Philippe 2016; Schardl et al. 2004; Young et al. 2013); thus, an endophyte could provide a refuge for its host grass from grazing animals and insects in grassland ecosystems by deterring mammalian herbivores and insect vectors of pathogenic fungi from feeding on it (Yao et al. 2015). In this way, the possibility of pathogens infecting the grass by mechanical wounds caused by mammalian herbivore foraging would be greatly decreased (Daleo et al. 2009). In addition, excluding mammalian herbivores and insect vectors of pathogenic fungi contributed to a decrease in the concentration of pathogenic fungi around E+ grasses (Gao and Nan 2007; Latch 1993; Nan and Li 2004), consequently reducing the risk of host plants being infected by disease pathogens (Fig. 1A). The relevant research carried out by West et al. (1990) using tall fescue has confirmed this view.

In addition to alkaloids, volatile organic compounds (VOCs) are another kind of crucial secondary metabolite in grass-endophyte symbioses that act as a defense mechanism to regulate plant resistance (Bakkali et al. 2008). They are usually substances that are relatively low in molecular weight (less than $300 \mathrm{Da}$ ), have strong volatility, and have organic compounds with low polarity but very high vapor pressure (Vespermann et al. 2007). VOCs, derived from plant tissues, play a crucial role in plant-insect interaction systems (Yue et al. 2001), and their types and contents are different between E+ and E- grasses (Zhang et al. 2012, 2014, 2015), especially when the grasses are infected by pathogens (Pańka et al. 2013b). Similar to alkaloids, by repelling insects, the VOCs could cut off the transmission route of pathogen spores caused by the insects visiting the host and neighboring grasses (García Parisi et al. 2014). Thereby, VOCs also indirectly reduce the possibility of host plants being infected by disease pathogens (Fig. 1A).

Occupation of ecological niches. The first step in the colonization of plants by many pathogens is the penetration of the leaf surface to grow and develop inside plant tissues. The presence of endophytes may form a defensive barrier against initial colonization of the leaf surface. Moreover, the endophyte mycelium on the leaf (epiphyllous net) may occupy space and use available nutrients, although not every species of endophyte has an epiphyllous stage (Clarke et al. 2006). Thus, potential pathogens cannot obtain nutrients and are not able to continue successful growth (Moy et al. 2000). In other words, endophytes could enhance disease resistance through competition for nutrients with pathogens and spatial niche exclusion.

When pathogens break through the physical barriers of plants, the pattern recognition receptors of plants recognize the general features of the microbial pathogens, and inducible defenses can be activated (Jones and Dangl 2006; Pel and Pieterse 2013). In consideration of the fact that Epichloë endophytes may be derived from biotrophic pathogens (Wang et al. 2016), it is tempting to speculate that endophytes, although usually not causing any disease effects, induce a weak resistance response or cause the host's immune system to enter a latent activation state in infected plants (Malinowski and Belesky 2000). This makes the E+ plants much more sensitive than E- plants to biotrophic pathogen invasion, and symbiotic plants can activate a defense reaction more rapidly than nonsymbiotic plants when being attacked (Pańka et al. 2013a). In other words, endophytes could enhance disease resistance through an advanced activation of the host's immune system by occupying a temporal niche.

Promotion of host grass growth. In some cases, endophytes can accelerate seedling emergence and promote plant establishment under adverse conditions and enhance plant growth and development. Furthermore, they can improve the resistance of host plants to disease (Xia et al. 2016). However, the better growth and appearance of the grasses may sometimes in turn contribute indirectly to the development 
of disease (Wiewióra et al. 2015). Overall protection mediated by an endophyte has been observed in several symbioses occurring during different stages of the plant life cycle (Pérez et al. 2013, 2016; Tian et al. 2008; Vignale et al. 2013; Wäli et al. 2006; Welty et al. 1991).

Inhibiting the development of disease. Molecules and proteins. A SOLiD-SAGE quantitative transcriptome comparison of E- and $E$. festucae-infected red fescue indicated that many of the abundantly expressed fungal genes were for a secreted antifungal protein, and these genes were similar to the antifungal activity genes found in Penicillium and Aspergillus spp. This evidence suggests that these abundantly expressed genes may be involved in the disease resistance conferred to the host by the Epichloë endophyte (Ambrose and Belanger 2012). The second most abundantly expressed gene, Efe-afpA, has been shown to encode an antifungal protein, Efe-AfpA. This protein is abundant in host plant apoplasts, which suggests it could come into contact with invading fungal pathogens and may be a factor in the disease resistance observed in E+ red fescue. This is because the purified Efe-AfpA protein has shown strong inhibition of the growth of the pathogen Sclerotinia homoeocarpa by damaging the fungi's plasma membrane in vitro (Tian et al. 2017). In addition to E. festucae, E. inebrians is another type of Epichloë endophyte of the 10 with whole genome sequences available that has related antifungal protein genes (Ambrose and Belanger 2012). However, there are some other studies indicating that the presence of an endophyte would down-regulate the pathogenesis-related (PR) genes in tall fescue (Johnson et al. 2003) and perennial ryegrass (Dupont et al. 2015). However, it is important to note that this effect was observed under a normal growth environment without any pathogenic stress, and there is still no definitive proof showing that the down-regulated PR genes are directly related to lower disease resistance.
Antioxidant substances. Plants produce and accumulate reactive oxygen species (ROS) during aerobic metabolism (Apel and Hirt 2004). Under normal situations, the antioxidant production of plants would be sufficient to meet the need to scavenge these ROS. The equilibrium between ROS production and antioxidant scavenging would be perturbed when responding to various stresses, consequently increasing the possibility of cell death (Foyer and Noctor 2011; Hamilton and Bauerle 2012), and ROS production may induce a switch in the Epichloe endophyte from being a mutualist to being a pathogen (Eaton et al. 2011). In addition to aerobic metabolism, plants also produce and accumulate ROS following recognition of various pathogens, which is regarded as one of the earliest cellular responses for successful pathogen recognition (Auh and Murphy 1995; Grant et al. 2000). It has been reported that the presence of endophytes increased the activity of antioxidants in host grasses, further increasing the ability of the host plant to scavenge ROS resulting from abiotic stress (Fig. 1B) (Hamilton et al. 2012). The process of endophyte resistance to plant disease also manifested as the same phenomena under pathogenic stress, with the activity of antioxidant substances such as superoxide dismutase (SOD) and peroxidases (POD) in E+ perennial ryegrass being stronger than that in E- grass (Ma et al. 2015; Tian et al. 2008). E+ drunken horse grass also had a stronger active SOD and POD under powdery mildew stress than Egrass. A trial assessing disease resistance of wild barely also obtained the same results, namely, that the presence of endophytes increased the SOD and catalase (CAT) activity of the host grass under five types of pathogenic stress (Sun 2015). Another scavenger substance of ROS, proline, which can be involved in cell wall reinforcement, also increased in E+ grass under pathogen stress (Ma et al. 2015). Malondialdehyde (MDA) is a key indicator for evaluating the status of plants' redox and is one of the ultimate products of lipid

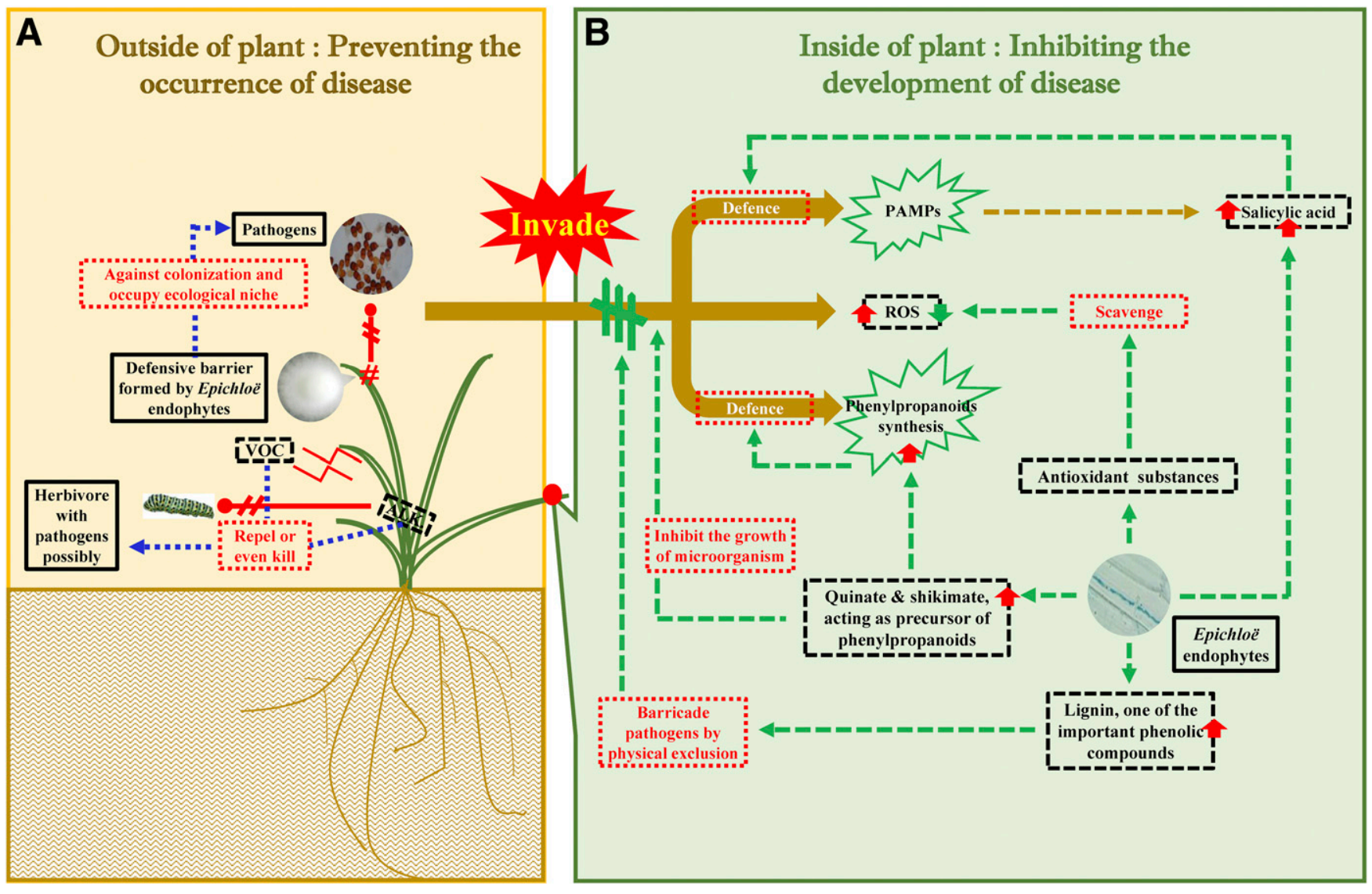

Fig. 1. Communication between symbionts and pathogens mediated by Epichloë endophytes. The presence of endophytes forms a defensive barrier against initial colonization of the leaf surface (A). Secondary metabolites, including volatile organic compounds (VOC) and alkaloids (ALK), and defense compounds in plant cells are induced due to pathogen infection. The secondary metabolites repel or even kill herbivores, consequently reducing the spread of insect-transmitted disease in grass. After invasion by pathogens (B), the pathogen-associated molecular patterns (PAMPs) are activated, large quantities of reactive oxygen species (ROS) are produced, and the phenylpropanoids are synthesized. The defensive compounds in the plant cell are also mobilized to resist the invasion of pathogens by eliminating all these adverse changes. 
peroxidation damage. MDA concentration is related to the degree of membrane lipid peroxidation (Bailly et al. 1996). Under pathogen stress, MDA content was significantly lower in E+ perennial ryegrass than in E- perennial ryegrass (Ma et al. 2015). The trial carried out on wild barely obtained similar results (Sun et al. 2015). This may be because the presence of an endophyte relieves the damage of disease to cell membranes of the host grass.

Alkaloids. Based on previous research, we proposed that the documentation of higher levels of alkaloids in host plants may promote the ability of host defense against pathogens (Leuchtmann et al. 2000), but this ability seems to only be effective during the seed and seedling stage, when pathogen infection has more direct effects on plant fitness (Faeth 2002; Knoch et al. 1993). There is evidence showing that extracting solution containing alkaloids can inhibit pathogenic fungi growth and spore germination directly. However, whether there were any other specific chemical substances in the solution playing an antifungal role is still uncertain (Sun et al. 2015). However, some evidence suggests that alkaloids had no fungal effect, at least in vitro (Siegel and Latch 1991), and it has been proposed that antifungal substances may not be alkaloids (Holzmann-Wirth et al. 2000; Wang et al. 2016). However, it is worth noting that the alkaloid concentration produced by the endophyte itself is far lower than the concentration produced by the endophyte-grass symbiosis (Li 2005). Therefore, the direct effects of alkaloids on host plant resistance to diseases are still controversial.

Phytohormones. The increasing production of plant hormones may also promote microbial symbiosis and an increase in stress resistance (Saikkonen et al. 2013). Salicylic acid (SA) plays a crucial role in activating plant defense responses to biotic stresses (Edgar et al. 2006; Vlot et al. 2009), and its levels are regarded as closely related to plant disease reaction. The invasion by biotrophic pathogens would primarily induce and activate the SA-dependent defenses of a plant, which would in turn be effective against biotrophic pathogens by activating a large set of defense-related genes. These defense-related genes are used to code for PR proteins and WRKY transcription factors (Fig. 2) (Vos et al. 2013). These PR proteins are able to compose various enzymes, some of which may act to lyse the invading cells, reinforce the cell wall to resist infections, induce localized cell death, etc. (Gao et al. 2010). It is worth noting that many endophytes, including Epichloë endophytes, may be derived from biotrophic pathogens and strictly asexual; therefore, an endophyte infection may be beneficial to activate the SA-dependent signaling pathway in plants. An experiment has shown that E+Chinese wildrye plants have a higher SA content than E- plants, especially when they are exposed to B. sorokiniana and C. lunata (Fig. 1B) (Wang et al. 2016). Different from SA-dependent defenses, which are effective against biotrophic pathogens, jasmonic acid (JA)-dependent defenses are effective against necrotrophic pathogens by participating in the activation of the ERF-branch, which results in the activation of the marker gene PLANT DEFENSIN 1.2 (Fig. 2) (Vos et al. 2013). However, to date, there is no evidence that an endophyte could participate in improving the disease resistance of host plants by regulating JA content. However, there was an experiment on tall fescue symbiosis with the E. coenophialum endophyte indicating increased expression of the TFF41 gene in response to the symbiosis. The TFF41 protein encoded by the TFF41 gene is extremely similar to the $\omega-3$ FAD enzymes, which increase the abundance of trienoic fatty acids and are precursors of JA (Johnson et al. 2003). However, whether the upregulation of the TFF41 gene leads to an increase in JA synthesis still needs to be verified (Bastias et al. 2017).

Phenolic substances. In addition to alkaloids, endophytes induce their host grass to produce phenolic substances to improve their disease resistance. Quinate and shikimate are the precursors of aromatic amino acids and are the compounds necessary for the synthesis of the phenylpropanoids (Herrmann and Weaver 1999) that are involved in plant defense responses (Dixon 2001). Studies have shown that the

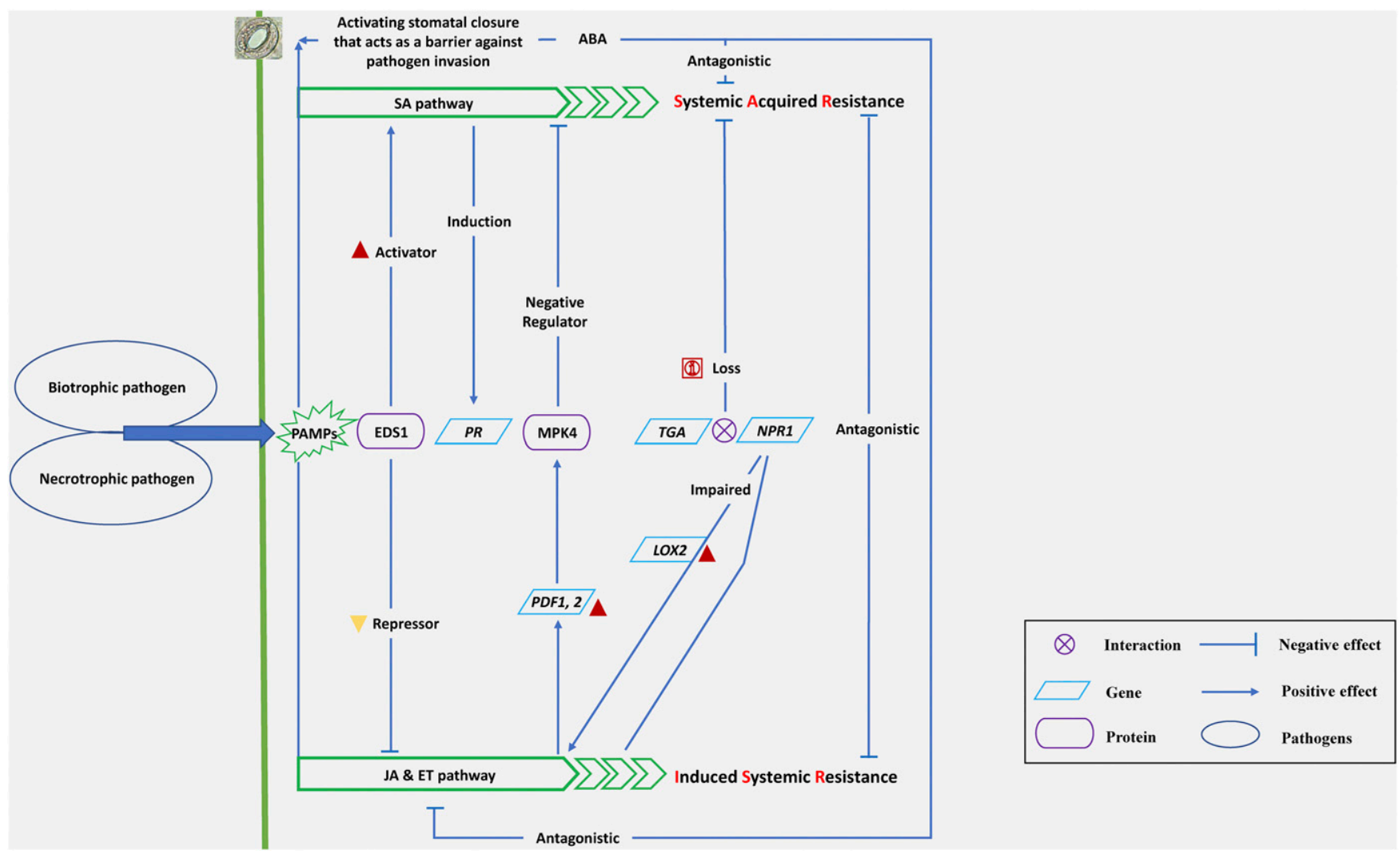

Fig. 2. Selected features of the salicylate and jasmonate defense signaling pathways. Pathogen stress results in changes in different phytohormone levels, especially salicylic acid $(\mathrm{SA})$, jasmonate $(\mathrm{JA})$, and ethylene (ET). Two different pathways further regulating two different types of disease resistance are mediated through these three kinds of hormones The crosstalk between two signaling pathways can be either antagonistic or cooperative, and there are more cases of antagonism than cooperation. Alterations in hormone levels result in changes in the expression of defense-related genes and the activation of related proteins, and the relationship between two signaling pathways is also regulated by these related genes and proteins. 
presence of an endophyte increases quinate and shikimate content in E+ perennial ryegrass and tall fescue (Malinowski et al. 1998; Rasmussen et al. 2008), which may further result in an increase in phenylpropanoids in the host grass (Fig. 1B). However, when grasses were infected by pathogens, the production of phenylalanine, which also acts as a major aromatic acid precursor for phenylpropanoid, in $\mathrm{E}+$ grass was lower than in E- grass, but the glutamine content was higher in E+ grass than in E- grass (Wang et al. 2016). Glutamine accumulation can reflect an activation of plant defense systems against pathogen infection (Forde and Lea 2007). This seems to be inconsistent with the change in phenylalanine. However, it is important to note that phenylalanine is the intermediate metabolite for phenylpropanoid metabolism, and thus when plants are attacked by pathogens, the endophyte may exact a cost by depleting the induced phenylalanine to produce other defense compounds, such as lignin (Dixon 2001; Wang et al. 2016). Lignin, as one of the important phenolic compounds, was regarded as a chemical used for reinforcement of cell walls (Farmer 1985). The research on perennial ryegrass found that the presence of an endophyte can promote the lignin production of host grass under normal conditions without pathogen stress (Qawasmeh et al. 2012; Torres et al. 2012). Lignin production was regarded as a potential protective method that barricades the pathogen from invading the plant (Funnell-Harris et al. 2010). Additionally, lignin and total phenolic content were also increased after infection by pathogens, and the content in E+ grass was still much higher than in E- grass (Fig. 1B) (Pańka et al. 2013a, b; Wang et al. 2016). This was regarded as additional strong evidence that lignin positively affected the resistance of plants to pathogens.

Other antifungal activity substances. Furthermore, Niones and Takemoto (2014) reported that endophytes produced a thermostable, low-molecular weight antifungal compound in culture, which reduced the hyphal tip growth and differentiation of the pathogen. Additionally, 17 types of secondary metabolic compounds were isolated from E+ Elymus tangutorum grass. One of these, cyclosporin T, strongly inhibits the growth of $A$. alternata, $B$. sorokiniana, $C$. lunata, and $F$. avenaceum in vitro (Song et al. 2015). The volatile oils obtained from E+ drunken horse grass also had a stronger inhibitory effect on pathogen growth than those produced by E- grass in vitro (Zhang et al. 2015), which indicated that volatile oils may directly enhance the pathogen resistance of host grass by inhibiting the growth of pathogens.

\section{Conclusion and Perspectives}

There are increasing numbers of researchers focusing on the resistance of the Epichloë endophytes to plant pathogens. The present review verified the resistance of Epichlö̈ endophytes and their symbiosis with fungal pathogens or plant diseases by summarizing three types of trials, including a dual-culture test, a detached-leaves test, and an in planta test. However, the main results obtained from these trials are inconsistent. Therefore, a general conclusion regarding endophyte-mediated grass resistance to pathogens is difficult to formulate. Specific species of endophytes may protect their host grass from pathogenic stress under specific environmental conditions. In other words, the resistance of an Epichloë endophyte to a pathogen is affected by multiple factors, such as the genotypes of the Epichlö̈ endophyte and host plant and environmental factors. We attempt to understand the multiple effects of Epichloë endophytes on plant resistance to pathogenic fungi and highlight our understanding of grass-endophyte symbiosis at the mechanistic level. Thus, further experimental research is needed to enhance our understanding of the disease resistance mechanisms. We may be able to utilize the results from manipulative experiments to identify changes in gene and metabolite levels and protein functions to develop theoretical models regarding the resistance of endophytes and symbioses to pathogens and plant diseases. We should also learn from other symbioses for which more information exists, such as plant-mycorrhizal interactions and plant-bacterial interactions. Only in this way can we learn more about the mechanisms of how endophytic fungi increase the pathogen resistance of host plants and with this beneficial knowledge, breed new disease-resistant varieties of grass using Epichloë endophytes in the future.

\section{Acknowledgments}

We apologize to colleagues whose work could not be cited owing to space limitations. We sincerely thank anonymous reviewers for reviewing the manuscript, and Dr. Yuan Li of Lincoln University, New Zealand, for collecting the literature.

\section{Literature Cited}

Ambrose, K. V., and Belanger, F. C. 2012. SOLiD-SAGE of endophyte-infected red fescue reveals numerous effects on host transcriptome and an abundance of highly expressed fungal secreted proteins. PLoS One 7:e53214.

Apel, K., and Hirt, H. 2004. Reactive oxygen species: metabolism, oxidative stress, and signal transduction. Annu. Rev. Plant Biol. 55:373-399.

Auh, C. K., and Murphy, T. M. 1995. Plasma membrane redox enzyme in involved in the synthesis of $\mathrm{O}^{2-}$ and $\mathrm{H}_{2} \mathrm{O}_{2}$ by Phytiphthora elicitor-stimulated rose cell. Plant Physiol. 107:1241-1247.

Bacon, C. W., Porter, J. K., Robbins, J. D., and Luttrell, E. S. 1977. Epichlö̈ typhina from toxic tall fescue grasses. Appl. Environ. Microbiol. 34:576-581.

Bailly, C., Benamar, A., Corbineau, F., and Come, D. 1996. Changes in malondialdehyde content and in superoxide dismutase, catalase and glutathione reductase activities in sunflower seeds as related to deterioration during accelerated aging. Physiol. Plantarum 97:104-110.

Bakkali, F., Averbeck, S., Averbeck, D., and Idaomar, M. 2008. Biological effects of essential oils-a review. Food Chem. Toxicol. 46:446-475.

Barker, G. M., Patchett, B. J., and Cameron, N. E. 2015. Epichloë uncinata infection and loline content protect Festulolium grasses from crickets (Orthoptera: Gryllidae). J. Econ. Entomol. 108:789-797.

Bastias, D. A., Martinez-Ghersa, M. A., Ballare, C. L., and Gundel, P. E. 2017. Epichloë fungal endophytes and plant defenses: Not just alkaloids. Trends Plant Sci. 22:939-948.

Bonos, S. A., Wilson, M. M., Meyer, W. A., and Funk, C. R. 2005. Suppression of red thread in fine fescues through endophyte-mediated resistance. Appl Turfgrass Sci. 10:1094.

Bourgaud, F., Gravot, A., Milesi, S., and Gontier, E. 2001. Production of plant secondary metabolites: a historical perspective. Plant Sci. 161:839-851.

Bush, L. P., Wilkinson, H. H., and Schardl, C. L. 1997. Bioprotective alkaloids of grass-fungal endophyte symbioses. Plant Physiol. 114:1-7.

Chen, N., He, R. L., Chai, Q., Li, C. J., and Nan, Z. B. 2016. Transcriptomic analyses giving insights into molecular regulation mechanisms involved in cold tolerance by Epichlö̈ endophyte in seed germination of Achnatherum inebrians. Plant Growth Regul. 80:367-375.

Chen, W., Liu, H., Han, W., Gao, Y., Card, S. D., and Ren, A. 2017. The advantages of endophyte-infected over uninfected tall fescue in the growth and pathogen resistance are counteracted by elevated $\mathrm{CO}_{2}$. Sci. Rep. 7:6952.

Cheplick, G. P., and Clay, K. 1988. Acquired chemical defences in grasses: the role of fungal endophytes. Oikos 52:309-318.

Christensen, M. J. 1996. Antifungal activity in grasses infected with Acremonium and Epichlö̈ endophytes. Australas. Plant Pathol. 25:186-191.

Christensen, M. J., and Latch, G. C. M. 1991. Variation among isolates of Acremonium endophytes (A. coenophialum and possibly A. typhinum) from tall fescue (Festuca arundinacea). Mycol. Res. 95:1123-1126.

Christensen, M. J., Bennett, R. J., Ansari, H. A., Koga, H., Johnson, R. D., Bryan, G. T., Simpson, W. R., Koolaard, J. P., Nickless, E. M., and Voisey, C. R. 2008 Epichlö endophytes grow by intercalary hyphal extension in elongating grass leaves. Fungal Genet. Biol. 45:84-93.

Christensen, M. J., Latch, G. C. M., and Tapper, B. A. 1991. Variation within isolates of Acremonium endophyte from perennial rye-grass. Mycol. Res. 95:918-923.

Chu-Chou, M., Guo, B., An, Z. Q., Hendrix, J. W., Ferriss, R. S., Siegel, M. R., Dougherty, C. T., and Burrus, P. B. 1992. Suppression of mycorrhizal fungi in fescue by the Acremonium coenophialum endophyte. Soil Biol. Biochem. 24: 633-637.

Clarke, B. B., White, J. F., Jr., Hurley, R. H., Torres, M. S., Sun, S., and Huff, D. R. 2006. Endophyte-mediated suppression of dollar spot disease in fine fescues. Plant Dis. 90:994-998.

Daleo, P., Silliman, B., Alberti, J., Escapa, M., Canepuccia, A., Peña, N., and Iribarne, O. 2009. Grazer facilitation of fungal infection and the control of plant growth in south-western Atlantic salt marshes. J. Ecol. 97:781-787.

Dinneny, J. R. 2015. Traversing organizational scales in plant salt-stress responses. Curr. Opin. Plant Biol. 23:70-75.

Dixon, R. A. 2001. Natural products and plant disease resistance. Nature 411: 843-847.

Dupont, P., Eaton, C. J., Wargent, J. J., Fechtner, S., Solomon, P., Schmid, J., Day, R. C., Scott, B., and Cox, M. P. 2015. Fungal endophyte infection of ryegrass reprograms host metabolism and alters development. New Phytol. 208: 1227-1240.

Eaton, C. J., Cox, M. P., and Scott, B. 2011. What triggers grass endophytes to switch from mutualism to pathogenism? Plant Sci. 180:190-195.

Edgar, C. I., McGrath, K. C., Dombrecht, B., Manners, J. M., Maclean, D. C., Schenk, P. M., and Kazan, K. 2006. Salicylic acid mediates resistance to the vascular wilt pathogen Fusarium oxysporum in the model host Arabidopsis thaliana. Australas. Plant Pathol. 35:581-591. 


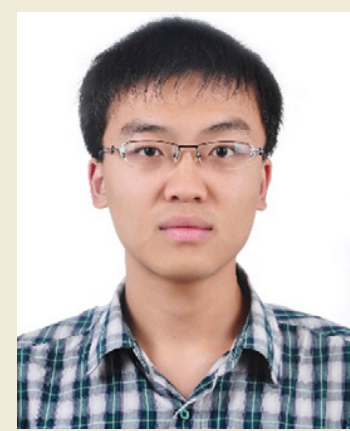

Chao Xia

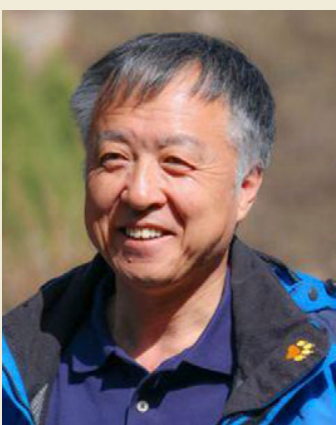

Chunjie Lì

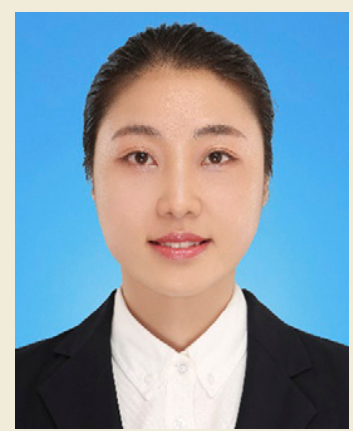

Nana Li

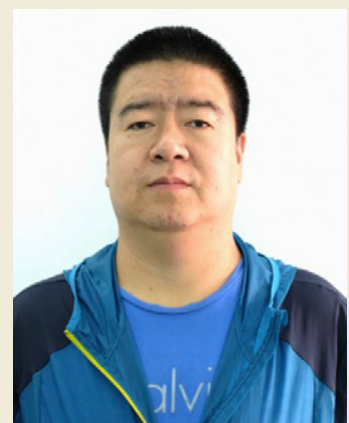

Xingxu Zhang

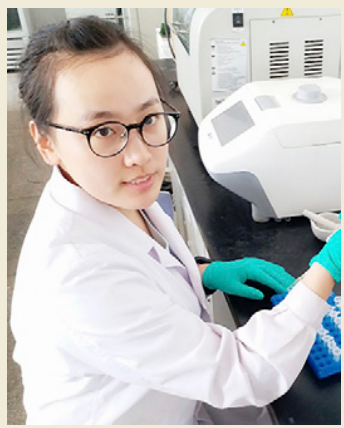

Yawen Zhang

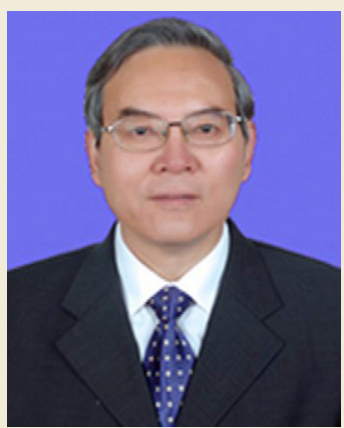

Zhibiao Nan

Dr. Chao Xia is an associate research fellow at the College of Pastoral Agricultural Science and Technology, Lanzhou University, China. He received a B.S. from Northwest A\&F University, China, in 2013, and a Ph.D. from Lanzhou University in 2018. His research included the effects of endophyte and soil water content on Achnatherum inebrians resistance to powdery mildew disease caused by Blumeria graminis, as well as the mechanism of the interaction between Epichloë endophyte and $A$. inebrians under drought stress.

Nana $\mathrm{Li}$ is a postgraduate student at the College of Pastoral Agricultural Science and Technology, Lanzhou University, China. She received her B.S. from Gansu Agricultural University, China, in 2015. Her research is mainly focused on the effects of the interaction between Epichloe endophyte and soil water content on the Blumeria graminis resistance of Achnatherum inebrians.

Yawen Zhang is a Ph.D. student at the College of Pastoral Agricultural Science and Technology, Lanzhou University, China. She received a B.S. from Northwest A\&F University, China, in 2013. Her research is mainly focused on the identification and taxonomy of fungal diseases on natural grasslands, and exploration the relationship between grazing and grassland diseases. She has reported two new disease on Leymus chinensis in China.

Dr. Chunjie Li is a professor at the College of Pastoral Agricultural Science and Technology, Lanzhou University, China. He received his Ph.D. in grass endophyte ecology at Lanzhou University in 2005 . His research fields include identification and

taxonomy of fungal pathogens and endophytes on grasslands, exploration of mutualistic relationships, including stress tolerance, alkaloids, herbivore intoxicating, novel endophyte breeding and ecology, between grasses and Epichloë endophytes in China. Dr. $\mathrm{Li}$ is one of the pioneers of grass endophyte research in China, naming two Epichloë endophytes of Achnatherum inebrians: Epichloë gansuensis and $E$. inebrians.

Dr. Xingxu Zhang is an associate professor at the College of Pastoral Agricultural Science and Technology, Lanzhou University, China. He received a B.S. from Hexi University, China, in 2005, and an M.S. and Ph.D. from Lanzhou University in 2008 and 2012, respectively. His research is mainly focused on the interaction between fungi and host grasses under stresses, and his research has also focused on the plant diseases and their control in grassland, seed pathology, and seed health evaluation.

Dr. Zhibiao Nan is a professor in grassland science at the College of Pastoral Agricultural Science and Technology, Lanzhou University, China. He received his Ph.D. in plant science at Massey University, and AgResearch (then Grasslands Division, DSIR), Palmerston North, New Zealand, in 1989. He is one of the leading forage pathologists in China. His research fields include fungal diseases of forage crops, grass endophyte, and interactions of livestock grazing and grassland plant diseases. Dr. Nan is a member of the Chinese Academy of Engineering, a lifetime honor awarded to outstanding scientists and engineers. He also received the lifetime achievement award from the Chinese Society for Plant Pathology in 2017.

Eerens, J. P. J., Visker, M. H., Lucas, R. J., and White, J. G. H. 1998. Influence of the ryegrass endophyte (Neotyphodium lolii) in a cool moist environment IV. Plant parasitic nematodes. N. Zeal. J. Agr. Res. 41:209-217.

Faeth, S. H. 2002. Are endophytic fungi defensive plant mutualists? Oikos 98: 25-36.

Farmer, E. E. 1985. Effects of fungal elicitor on lignin biosynthesis in cell suspension cultures of boybean. Plant Physiol. 78:338-342.

Filipov, N. M., Thompson, F. N., Hill, N. S., Dawe, D. L., Stuedemann, J. A., Price, J. C., and Smith, C. K. 1998. Vaccination against ergot alkaloids and the effect of endophyte-infected fescue seed-based diets on rabbits. J. Anim. Sci. 76:2456-2463

Fisher, M. C., Henk, D. A., Briggs, C. J., Brownstein, J. S., Madoff, L. C., McCraw, S. L., and Gurr, S. J. 2012. Emerging fungal threats to animal, plant and ecosystem health. Nature 484:186-194.

Forde, B. G., and Lea, P. J. 2007. Glutamate in plants: metabolism, regulation, and signalling. J. Exp. Bot. 58:2339-2358.

Foyer, C. H., and Noctor, G. 2011. Ascorbate and glutathione: the heart of the redox hub. Plant Physiol. 155:2-18.

Funnell-Harris, D. L., Pedersen, J. F., and Sattler, S. E. 2010. Alternation in lignin biosynthesis restricts growth of Fusarium spp. in brown midrib sorghum. Phytopathology 100:671-681.

Gao, F. K., Dai, C. C., and Liu, X. Z. 2010. Mechanisms of fungal endophytes in plant protection against pathogens. Afr. J. Microbiol. Res. 4:1346-1351.

Gao, J. H., and Nan, Z. B. 2007. A review of bioprotective alkaloids of grass fungal endophyte symbioses. Acta Ecol. Sin. 27:2531-2546 (In Chinese with English abstract).

García Parisi, P. A., Grimoldi, A. A., and Omacini, M. 2014. Endophytic fungi of grasses protect other plants from aphid herbivory. Fungal Ecol. 9:61-64. 
Górzyńska, K., Ryszka, P., Anielska, T., Turnau, K., and Lembicz, M. 2017. Effect of Epichloë typhina fungal endophyte on the diversity and incidence of other fungi in Puccinellia distans wild grass seeds. Flora 228:60-64.

Grant, M., Brown, I., Adams, S., Knight, M., Ainslie, A., and Mansfield, J. 2000. The RPMI plant disease resistance gene facilitates a rapid and sustained increase in cytosolic calcium that is necessary for the oxidative burst and hypersensitive cell death. Plant J. 23:441-450.

Gundel, P. E., Irisarri, J. G. N., Fazio, L., Casas, C., and Pérez, L. I. 2016. Inferring field performance from drought experiments can be misleading: The case of symbiosis between grasses and Epichlö fungal endophytes. J. Arid Environ. 132:60-62.

Guo, C. H., Li, X. Z., Liu, L., Cao, J. X., and Li, C. J. 2016. Effect of the Epichloë endophyte on the soil nematode community in the rhizosphere of Achnatherum inebrians. Acta Pratac. Sin. 25:140-148 (In Chinese with English abstract).

Guy, P. L. 1992. Incidence of Acremonium lolii and lack of correlation with barley yeallow dwarf viruses in Tasmanian perennial ryegrass pasture. Plant Pathol. 41:29-34.

Guy, P. L, and Davis, L. T. 2002. Variation in the incidence of barley yellow dwarf virus and in the ability of Neotyphodium endophytes to deter feeding by aphids (Rhopalosiphum padi) on Australasian tall fescue. Australas. Plant Pathol. 31: 307-308.

Gwinn, K. D., and Gavin, A. M. 1992. Relationship between endophyte infestation level of tall fescue seed lots and Rhizoctonia zeae seedling disease. Plant Dis. 76:911-914

Hahn, H., McManus, M. T., Warnstorff, K., Monahan, B. J., Young, C. A., Davies, E., Tapper, B. A., and Scott, B. 2008. Neotyphodium fungal endophytes confer physiological protection to perennial ryegrass (Lolium perenne $\mathrm{L}$.) subjected to a water deficit. Environ. Exp. Bot. 63:183-199.

Hamilton, C. E., and Bauerle, T. L. 2012. A new currency for mutualism? Fungal endophytes alter antioxidant activity in hosts responding to drought. Fungal Divers. 54:39-49.

Hamilton, C. E., Gundel, P. E., Helander, M., and Saikkonen, K. 2012. Endophytic mediation of reactive oxygen species and antioxidant activity in plants: a review. Fungal Divers. 54:1-10.

Herrmann, K. M., and Weaver, L. M. 1999. The shikimate pathway. Annu. Rev. Plant Biol. 50:473-503.

Hesse, U., Schöberlein, W., Wittenmayer, L., Förster, K., Warnstorff, K., Diepenbrock, W., and Merbach, W. 2003. Effects of Neotyphodium endophytes on growth, reproduction and drought-stress tolerance of three Lolium perenne L. genotypes. Grass Forage Sci. 58:407-415.

Holzmann-Wirth, A., Dapprich, P., Eierdanz, S., Heerz, D., and Paul, V. H. 2000. Anti-fungal substances extracted from Neotyphodium endophytes. Pages 65-69 in: Proceedings of the 3rd International Conference on Harmful and Beneficial Microorganisms in Grassland, Pasture and Turf. V. H. Paul and P. D. Dapprich, eds. Universitat-Gesamthochschule Paderborn, Soest, Nordrhein-Westfalen, Germany.

Huang, X. Q., and Roder, M. S. 2004. Molecular mapping of powdery mildew resistance genes in wheat: a review. Euphytica 137:203-223.

Hume, D. E., Quigley, P. E., and Aldaoud, R. 1997. Influence of Neotyphodium infection on plant survival of diseased tall fescue and ryegrass. Pages 171-173 in: Neotyphodium/Grass interactions. C. W. Bacon and N. S. Hill, eds. Plenum Press, New York.

Iannone, L. J., Vignale, M. V., Pinget, A. D., Re, A., Mc Cargo, P. D., and Novas, M. V. 2017. Seed-transmitted Epichlö̈ sp. endophyte alleviates the negative effects of head smut of grasses (Ustilago bullata) on Bromus auleticus. Fungal Ecol. 29:45-51

Jarmusch, A. K., Musso, A. M., Shymanovich, T., Jarmusch, S. A., Weavil, M. J., Lovin, M. E., Ehrmann, B. M., Saari, S., Nichols, D. E., Faeth, S. H., and Cech, N. B. 2016. Comparison of electrospray ionization and atmospheric pressure photoionization liquid chromatography mass spectrometry methods for analysis of ergot alkaloids from endophyte-infected sleepygrass (Achnatherum robustum). J. Pharm. Biomed. 117:11-17.

Johnson, L. J., Johnson, R. D., Schardl, C. L., and Panaccione, D. G. 2003. Identification of differentially expressed genes in the mutualistic association of tall fescue with Neotyphodium coenophialum. Physiol. Mol. Plant Pathol. 63:305-317.

Jones, J. D. G., and Dangl, J. L. 2006. The plant immune system. Nature 444: 323-329.

Kane, K. H. 2011. Effects of endophyte infection on drought stress tolerance of Lolium perenne accessions from the Mediterranean region. Environ. Exp. Bot. 71:337-344

Knoch, T. R., Faeth, S. H., and Arnott, D. L. 1993. Endophytic fungi alter foraging and dispersal by desert seed-harvesting ants. Oecologia 95:470-473.

Kuldau, G., and Bacon, C. 2008. Clavicipitaceous endophytes: their ability to enhance resistance of grasses to multiple stresses. Biol. Control 46:57-71.

Latch, G. C. M. 1993. Physiological interactions of endophytic fungi and their hosts. Biotic stress tolerance imparted to grasses by endophytes. Agric. Ecosyst. Environ. 44:143-156.

Latch, G. C. M., Christensen, M. J., and Gaynor, D. L. 1985. Aphid detection of endophyte infection in tall fescue. N. Z. J. Agric. Res. 28:129-132.

Leuchtmann, A., Bacon, C. W., and Schardl, C. L. 2014. Nomenclatural realignment of Neotyphodium species with genus Epichloë. Mycologia 106: 202-215.
Leuchtmann, A., Schmidt, D., and Bush, L. P. 2000. Different levels of protective alkaloids in grasses with stroma-forming and seed-transmitted Epichloë/ Neotyphodium endophytes. J. Chem. Ecol. 26:1025-1036.

Li, C. J. 2005. Biological and ecological characteristics of Achnatherum inebrians/ Neotyphodium endophyte symbiont. PhD dissertation. Lanzhou University, China (In Chinese with English abstract).

Li, C. J., Gao, J. H., and Nan, Z. B. 2007a. Interactions of Neotyphodium gansuense, Achnatherum inebrians, and plant-pathogenic fungi. Mycol. Res. 111:1220-1227.

Li, C. J., Zhang, X. X., Li, F., Nan, Z. B., and Schardl, L. C. 2007b. Disease and pest resistance of endophyte infected and non-infected drunken horse grass. Pages 111-114 in: Proceedings of the 6th International Symposium on Fungal Endophytes of Grasses, A. Popay, and E. R. Thom, eds. New Zealand Grassland Association, Dunedin, Otago, New Zealand.

Liu, L., Guo, C. H., Lv, H., Gu, L. J., and Li, C. J. 2015. Effects of the Epichloë gansuensis endophyte on the disease resistance of drunken horse grass to powdery mildew. Acta Pratac. Sin. 24:65-71 (In Chinese with English abstract).

Ludwig-Müller, J. 2015. Plants and endophytes: equal partners in secondary metabolite production? Biotechnol. Lett. 37:1325-1334.

Ma, M. Z., Christensen, M. J., and Nan, Z. B. 2015. Effects of the endophyte Epichloë festucae var. lolii of perennial ryegrass (Lolium perenne) on indicators of oxidative stress from pathogenic fungi during seed germination and seedling growth. Eur. J. Plant Pathol. 141:571-583.

Ma, M. Z., and Nan, Z. B. 2011 b. Effect of fungal endophytes against rust disease of perennial ryegrass (Lolium perenne) on growth and physiological indices. Acta Pratac. Sin. 20:150-156 (In Chinese with English abstract).

Ma, M. Z., and Nan, Z. N. 2011a. Effect of fungal endophytes from perennial ryegrass on the growth of plant pathogens. Pratac. Sci. 28:962-968 (In Chinese with English abstract).

Mahmood, T., Gergerich, R. C., Milus, E. A., West, C. P., and Darcy, C. J. 1993 Barley yellow dwarf viruses in wheat, endophyte-infected and endophyte-free tall fescue, and other hosts in Arkansas. Plant Dis. 77:225-228.

Malinowski, D. P., Alloush, G. A., and Belesky, D. P. 1998. Evidence for chemica changes on the root surface of tall fescue in response to infection with the fungal endophyte Neotyphodium coenophoalum. Plant Soil 205:1-12.

Malinowski, D. P., and Belesky, D. P. 2000. Adaptation of endophyte-infected cool-season grasses to environmental stresses: Mechanisms of drought and mineral stress tolerance. Crop Sci. 40:923-940.

Malinowski, D. P., Zou, H., Belesky, D. P., and Alloush, G. A. 2004. Evidence for copper binding by extracellular root exudates of tall fescue but not perennial ryegrass infected with Neotyphodium spp. endophytes. Plant Soil 267:1-12.

Margulis, L. 1996. Archaeal-eubacterial mergers in the origin of Eukarya: phylogenetic classification of life. Proc. Natl. Acad. Sci. USA 93:1071-1076.

Moy, M., Belanger, F., Duncan, R., Freehoff, A., Leary, C., Meyer, W., Sullivan, R., and White, J. F., Jr. 2000. Identification of epiphyllous mycelial nets on leaves of grasses infected by Clavicipitaceous endophytes. Symbiosis 28 : 291-302.

Müller, C. B., and Krauss, J. 2005. Symbiosis between grasses and asexual fungal endophytes. Curr. Opin. Plant Biol. 8:450-456.

Nan, Z. B., and Li, C. J. 2000. Neotyphodium in native grasses in China and observations on endophyte/host interactions. Pages 41-50 in: Proceedings of 4th International Neotyphodium/Grass Interactions Symposium. V. H. Paul and P. D. Dapprich, eds. Fachbereich Agrarwirtschaft, Soest, NordrheinWestfalen, Germany.

Nan, Z. B., and Li, C. J. 2004. Roles of the grass-Neotyphodium association in pastoral agriculture systems. Acta Ecol. Sin. 24:605-616 (In Chinese with English abstract)

Niones, J. T., and Takemoto, D. 2014. An isolate of Epichloë festucae, an endophytic fungus of temperate grasses, has growth inhibitory activity against selected grass pathogens. J. Gen. Plant Pathol. 80:337-347.

Pal, K. K., and Gardener, B. M. 2006. Biological control of plant pathogens. The Plant Health Instructor.

Pańka, D. 2005. Infestation of tall fescue (Festuca arundinaceae Schreb.) with Neotyphodium coenophialum and its influence on growth of chosen microorganisms in vitro. Acta Agrobot. 58:369-380.

Pańka, D. 2008. Occurrence of Neotyphodium lolii and its antifungal properties Phytopathol. Pol. 48:5-12.

Pańka, D. 2011. Neotyphodium/Epichloë endophytes of perennial ryegrass, meadow fescue and red fescue cultivars cultivated in Poland. Acta Sci. Pol. Hortorum Cultus 10:111-131.

Pańka, D., Jeske, M., and Troczyński, M. 2011. Effect of Neotyphodium uncinatum endophyte on meadow fescue yielding, health status and ergovaline production in host-plants. J. Plant Prot. Res. 51:362-370.

Pańka, D., Lloveras, J., Gonzálezrodríguez, A., Vázquezyañez, O., and Piñeiro, J. 2006. Meadow fescue infestation with Neotyphodium uncinatum and influence of endophyte on growth of microorganisms in vitro. Pages 3-6 in: Sustainable grassland productivity: Proceedings of the 21st General Meeting of the European Grassland Federation. J. Lloveras, A. González-Rodríguez, O Vázquez-Yáñez, J. Piñeiro, O. Santamaría, L. Olea, and M. J. Poblaciones, eds. Badajoz, Extremadura, Spain.

Pańka, D., Piesik, D., Jeske, M., and Baturo-Ciesniewska, A. 2013a. Production of phenolics and the emission of volatile organic comp ounds by perennial 
ryegrass (Lolium perenne) Neotyphodium lolii association as a response to infection by Fusarium poae. J. Plant Physiol. 170:1010-1019.

Pańka, D., West, C. P., Guerber, C. A., and Richardson, M. D. 2013b. Susceptibility of tall fescue to Rhizoctonia zeae infection as affected by endophyte symbiosis. Ann. Appl. Biol. 163:257-268.

Pel, M. J. C., and Pieterse, C. M. J. 2013. Microbial recognition and evasion of host immunity. J. Exp. Bot. 64:1237-1248.

Pennell, C. G. L., and Rolston, M. P. 2012. Novel uses of grass endophyte technology. Pages 211-214 in: Proceedings 8th International Symposium on Fungal Endophyte of Grasses (ISFEG). Z. B. Nan and C. J. Li, eds. Lanzhou, Gansu, China.

Pérez, L. I., Gundel, P. E., Ghersa, C. M., and Omacini, M. 2013. Family issues: fungal endophyte protects host grass from the closely related pathogen Claviceps purpurea. Fungal Ecol. 6:379-386.

Pérez, L. I., Gundel, P. E., Marrero, H. J., Arzac, A. G., and Omacini, M. 2017. Symbiosis with systemic fungal endophytes promotes host escape from vector-borne disease. Oecologia 184:237-245.

Pérez, L. I., Gundel, P. E., and Omacini, M. 2016. Can the defensive mutualism between grasses and fungal endophytes protect non-symbiotic neighbours from soil pathogens? Plant Soil 405:289-298.

Philippe, G. 2016. Lolitrem B and indole diterpene alkaloids produced by endophytic fungi of the genus Epichlö̈ and their toxic effects in livestock. Toxins (Basel) 8:47.

Popay, A. J., and Bonos, S. A. 2005. Biotic responses in endophytic grasses. Pages 163-185 in: Neotyphodium in Cool-Season Grasses Current Research and Applications. C. Roberts, C. P. West, and D. Spiers, eds. Oxford, UK.

Qawasmeh, A., Obied, H. K., Raman, A., and Wheatley, W. 2012. Influence of fungal endophyte infection on phenolic content and antioxidant activity in grass: interaction between Lolium perenne and different strains of Neotyphodium lolii. J. Agric. Food Chem. 60:3381-3388.

Rasmussen, S., Parsons, A. J., Fraser, K., Xue, H., and Newman, J. A. 2008. Metabolic profiles of Lolium perenne are differentially affected by nitrogen supply, carbohydrate content, and fungal endophyte infection. Plant Physiol. 146:1440-1453.

Reddy, M. N., and Faeth, S. H. 2010. Damping-off of Festuca arizonica caused by Fusarium. Am. J. Plant Sci. 1:104-105.

Rivera-Varas, V. V., Freeman, T. A., Gudmestad, N. C., and Secor, G. A. 2007. Mycoparasitism of Helminthosporium solani by Acremonium strictum. Phytopathology 97:1331-1337.

Sabzalian, M. R., and Mirlohi, A. 2010. Neotyphodium endophytes trigger salt resistance in tall and meadow fescue. J. Plant Nutr. Soil Sci. 173:952-957.

Sabzalian, M. R., Mirlohi, A., and Sharifnabi, B. 2012. Reaction to powdery mildew fungus, Blumeria graminis in endophyte-infected and endophyte-free tall and meadow fescues. Australas. Plant Pathol. 41:565-572.

Saikkonen, K., Gundel, P. E., and Helander, M. 2013. Chemical ecology mediated by fungal endophytes in grasses. J. Chem. Ecol. 39:962-968.

Saikkonen, K., Lehtonen, P., Helander, M., Koricheva, J., and Faeth, S. H. 2006. Model systems in ecology: dissecting the endophyte-grass literature. Trends Plant Sci. 11:428-433.

Sampson, K. 1933. The systematic infection of grasses by Epichloë typhina (Pers.) Tul. Trans. Br. Mycol. Soc. 18:30-47.

Schardl, C. L., Leuchtmann, A., and Spiering, M. J. 2004. Symbioses of grasses with seedborne fungal endophytes. Annu. Rev. Plant Biol. 55:315-340.

Schardl, C. L., and Phillips, T. D. 1997. Protective grass endophytes: where are they from and where are they going. Plant Dis. 81:430-438.

Schmidt, D., and Scehovic, J. 1994. Results of one trial examining the influence of Acremonium uncinatum and leaf spot diseases on different chemical components and nutritive value of Festuca pratensis. Bulletin OILB/SROP, France.

Shiba, T., Koya, S., and Akira, A. 2011. Evaluating the fungal endophyte Neotyphodium occultans for resistance to the rice leaf bug, Trigonotylus caelestialium, in italian ryegrass, Lolium multiflorum. Entomol. Exp. Appl. 141:45-51

Shimanuki, T., and Sato, T. 1983. Occurrence of the choke disease on timothy caused by Epichloë typhina (Pers ex Fr.) Tul. Hokkaido and location of the endophytic mycelia with plant tissue. Res. Bull. Hokkaido Natl. Agric. Experiment Stn. 183:87-97.

Shymanovich, T., Charlton, N. D., Musso, A. M., Scheerer, J., Cech, N. B., Faeth, S. H., and Young, C. A. 2017. Interspecific and intraspecific hybrid Epichlö̈ species symbiotic with the North American native grass Poa alsodes. Mycologia 109:459-474

Siegel, M. R., and Latch, G. C. M. 1991. Expression of antifungal activity in agar culture by isolates of grass endophytes. Mycologia 83:529.

Song, H., Nan, Z. B., Song, Q. Y., Xia, C., Li, X. Z., Yao, X., Xu, W. B., Kuang, Y., Tian, P., and Zhang, Q. P. 2016. Advances in research on Epichlö̈ endophytes in Chinese native grasses. Front. Microbiol. 7:1399.

Song, M. L., Chai, Q., Li, X. Z., Yao, X., Li, C. J., Christensen, M. J., and Nan, Z. B. 2015a. An asexual Epichlö endophyte modifies the nutrient stoichiometry of wild barley (Hordeum brevisubulatum) under salt stress. Plant Soil 387:153-165.

Song, M. L., Li, X. Z., Saikkonen, K., Li, C. J., and Nan, Z. B. 2015b. An asexual Epichlö̈ endophyte enhances waterlogging tolerance of Hordeum brevisubulatum. Fungal Ecol. 13:44-52.

Song, Q. Y., Nan, Z. B., Gao, K., Song, H., Tian, P., Zhang, X. X., Li, C. J., Xu, W. B., and Li, X. Z. 2015. Antifungal, phytotoxic, and cytotoxic activities of metabolites from Epichlö̈ bromicola, a fungus obtained from Elymus tangutorum grass. J. Agric. Food Chem. 63:8787-8792.

Sun, Y. D. 2015. Effects of endophyte infection on fungal pathogens of wild barely (Hordeum brevisubulatum). MSc dissertation. Lanzhou University, China (In Chinese with English abstract).

Sun, Y. D., Zhang, X. X., Gu, L. J., Li, X. Z., Wang, P., and Li, C. J. 2015. Antifungal activity of the crude extraction of endophyte-infected and endophyte-free drunken horse grass. Pratac. Sci. 32:508-514 (In Chinese with English abstract).

Tadych, M., Bergen, M. S., and White, W. J., Jr. 2014. Epichloë spp. associated with grasses: new insights on life cycles, dissemination and evolution. Mycologia 106:181-201.

Tian, P., Nan, Z. B., Li, C. J., and Spangenberg, G. 2008. Effect of the endophyte Neotyphodium lolii on susceptibility and host physiological response of perennial ryegrass to fungal pathogens. Eur. J. Plant Pathol. 122:593-602

Tian, Z., Wang, R., Ambrose, K. V., Clarke, B. B., and Belanger, F. C. 2017. The Epichloë festucae antifungal protein has activity against the plant pathogen Sclerotinia homoeocarpa, the causal agent of dollar spot disease. Sci. Rep. 7:5643.

Torres, M. S., White, J. F. Jr., Zhang, X., Hinton, D. M., and Bacon, C. W. 2012 Endophyte-mediated adjustments in host morphology and physiology and effects on host fitness traits in grasses. Fungal Ecol. 5:322-330.

Trevathan, L. E. 1996. Performance of endophyte-free and endophyte-infected tall fescue seedlings in soil infected with Cochliobolus sativus. Can. J. Plant Pathol. 18:415-418.

Umbanhowar, J., and McCann, K. 2005. Simple rules for the coexistence and competitive dominance of plants mediated by mycorrhizal fungi. Ecol. Lett. 8:247-252.

Van Wees, S. C. M., Van der Ent, S., and Pieterse, M. J. C. 2008. Plant immune responses triggered by beneficial microbes. Curr. Opin. Plant Biol. 11:443-448

Vespermann, A., Kai, M., and Piechulla, B. 2007. Rhizobacterial volatiles affect the growth of fungi and arabidopsis thaliana. Appl. Environ. Microbiol. 73: $5639-5641$.

Vignale, M. V., Astiz-Gassó, M. M., Novas, M. V., and Iannone, L. J. 2013. Epichloid endophytes confer resistance to the smut Ustilago bullata in the wild grass Bromus auleticus (Trin.). Biol. Control 67:1-7.

Vlot, A. C., Dempsey, D. A., and Klessig, D. F. 2009. Salicylic acid, a multifaceted hormone to combat disease. Annu. Rev. Phytopathol. 47:177-206.

Vos, I. A., Pieterse, C. M. J., and Van Wees, S. C. M. 2013. Costs and benefits of hormone-regulated plant defences. Plant Pathol. 62:43-55.

Wäli, P. R., Helander, M., Nissinen, O., and Saikkonen, K. 2006. Susceptibility of endophyte-infected grasses to winter pathogens (snow molds). Can. J. Bot. 84: 1043-1051.

Walter, M., Harris-Virgin, P., Morgan, C., Stanley, J., Boyd-Wilson, K. S. H., Langford, G. I., and Moore, M. S. 2005. Fungicides for control of flower and berry infections of Botrytis cinerea in boysenberry. Crop Prot. 24: 625-631.

Wang, X. Y., Qin, J. H., Chen, W., Zhou, Y., Ren, A. Z., and Gao, Y. B. 2016 Pathogen resistant advantage of endophyte-infected over endophyte-free Leymus chinensis is strengthened by pre-drought treatment. Eur. J. Plant Pathol. 144:477-486.

Welty, R. E., and Barker, R. E. 1993. Reaction of twenty cultivars of tall fescue to stem rust in controlled and field environments. Crop Sci. 33:963-967.

Welty, R. E., Barker, R. E., and Azevedo, M. D. 1991. Reaction of tall fescue infected and noninfected by Acremonium coenophialum to Puccinia graminis subsp. graminicola. Plant Dis. 75:883

West, C. P., Izekor, E., Robbins, R. T., Gergerich, R., and Mahmood, T. 1990 Acremonium coenophialum effects on infestations of Barley Yellow Dwarf Virus and soil-borne nematodes and insects in tall fescue. Pages 196-198 in: Proc. Intl. Symp. On Acremonium/Grass Interactions. S. S. Quisenberry and R. E. Joost, eds. Agric. Exp. Stn., Baton Rouge, LA.

Wheatley, W. M., Nicol, H. I., Hunt, E. R., Nikandrow, A., and Cother, N. 2000 An association between perennial ryegrass endophyte, a leaf spot caused by Pyrenophora semeniperda and preferential grazing by sheep. Pages 71-75 in: The 3rd International Conference on Harmful and Beneficial Microorganisms in Grasslands, Pastures and Turf. V. H. Paul and P. D. Dapprich, eds Universität Paderborn, Soest, Germany.

White, J. F., Jr., and Cole, G. T. 1985. Endophyte-host associations in forage grasses. Mycologia 77:487-489.

Wiewióra, B., Żurek, G., and Żurek, M. 2015. Endophyte-mediated disease resistance in wild populations of perennial ryegrass (Lolium perenne). Fungal Ecol. 15:1-8.

Xia, C., Li, N. N., Zhang, X. X., Feng, Y., Christensen, M. J., and Nan, Z. B. 2016. An Epichlö endophyte improves photosynthetic ability and dry matter production of its host Achnatherum inebrians infected by Blumeria graminis under various soil water conditions. Fungal Ecol. 22:26-34.

Xia, C., Zhang, X. X., Christensen, M. J., Nan, Z. B., and Li, C. J. 2015. Epichloë endophyte affects the ability of powdery mildew (Blumeria graminis) to colonise drunken horse grass (Achnatherum inebrians). Fungal Ecol. 16: 26-33.

Xie, F. X., Ren, A. Z., Wang, Y., Lin, F., and Gao, Y. B. 2008. A comparative study of the inhibitive effect of fungal fungus pathogens. Acta Ecol. Sin. 28: 3913-3920. 
Yao, X., Christensen, M. J., Bao, G. S., Zhang, C. P., Li, X. Z., Li, C. J., and Nan, Z. B. 2015. A toxic endophyte-infected grass helps reverse degradation and loss of biodiversity of over-grazed grasslands in northwest China. Sci. Rep-UK 5: 18527.

Young, C., Schardl, C., Panaccione, D., Florea, S., Takach, J., Charlton, N., Moore, N., Webb, J., and Jaromczyk, J. 2015. Genetics, genomics and evolution of ergot alkaloid diversity. Toxins (Basel) 7:1273-1302.

Young, C. A., Hume, D. E., and Mcculley, R. L. 2013. Forages and pastures symposium: fungal endophytes of tall fescue and perennial ryegrass: pasture friend or foe? J. Anim. Sci. 91:2379-2394.

Yue, Q., Wang, C., Gianfagna, T. J., and Meyer, W. A. 2001. Volatile compounds of endophyte-free and infected tall fescue (Festuca arundinacea Schreb.). Phytochemistry 58:935-941.

Yule, K. M., Woolley, J. B., and Rudgers, J. A. 2011. Water availability alters the tritrophic consequences of a plant-fungal symbiosis. Arthropod-Plant Interact. 5: $19-27$

Zhang, X. X., Fan, X. M., Li, C. J., and Nan, Z. B. 2010a. Effects of cadmium stress on seed germination, seedling growth and antioxidative enzymes in
Achnatherum inebrians plants infected with a Neotyphodium endophyte. Plant Growth Regul. 60:91-97.

Zhang, X. X., Li, C. J., and Nan, Z. B. 2010b. Effects of cadmium stress on growth and anti-oxidative systems in Achnatherum inebrians symbiotic with Neotyphodium gansuense. J. Hazard. Mater. 175:703-709.

Zhang, X. X., Li, C. J., Nan, Z. B., and Matthew, C. 2012. Neotyphodium endophyte increases Achnatherum inebrians (drunken horse grass) resistance to herbivores and seed predators. Weed Res. 52:70-78.

Zhang, X. X., Wu, Y. P., and Nan, Z. B. 2014. Antifungal activity of petroleum ether extracts from Achnatherum inebrians infected with Neotyphodium gansuense. Sci. China Life Sci. 57:1234-1235.

Zhang, X. X., Xia, C., Li, C. J., and Nan, Z. B. 2015. Chemical composition and antifungal activity of the volatile oil from Epichlö gansuensis, endophyteinfected and non-infected Achnatherum inebrians. Sci. China Life Sci. 58:512-514.

Zhou, L. Y., Zhang, X. X., Li, C. J., Christensen, M. J., and Nan, Z. B. 2015 Antifungal activity and phytochemical investigation of the asexual endophyte of Epichloë sp. from Festuca sinensis. Sci. China Life Sci. 58: 821-826. 